\title{
Linking Diabetic Complications to Sorbitol Oxidation, Oxidative Stress and Metabolic Suppression \\ Joseph R Williamson ${ }^{1 *}$ and Yasuo Ido ${ }^{2}$
}

${ }^{1}$ Department of Pathology, Washington University School of Medicine, USA

${ }^{2}$ Departments of Medicine and Physiology, Boston Medical Center, EBRC 820, Diabetes and Metabolism Unit, Boston and University School of Medicine, Boston, MA, USA

\begin{abstract}
Significance: Numerous clinical trials implicate a key role for hyperglycemia in the pathogenesis of diabetic complications. Recent studies support the importance of oxidative stress in mediating these complications. Although it is well known that hyperglycemia increases the rates of glucose metabolism via glycolysis and the sorbitol pathway, the importance of their contributions to oxidative stress and diabetic complications remains controversial.

Recent advances and critical issues: The major objectives of this review are to draw attention to: 1) recent advances supporting the importance of oxidative stress linked to increased sorbitol oxidation in fueling oxidative stress evoked by hyperglycemia, 2) important caveats to interpretations of experimental observations using flawed experimental protocols and methods and/or inappropriate surrogate animal models of diabetes (i.e. galactosemia) thought to challenge or refute an important role for the sorbitol pathway in the pathogenesis of diabetic complications and 3) speculations not supported by credible evidence.
\end{abstract}

The first enzyme in the sorbitol pathway is Aldose Reductase (AR), which converts glucose to sorbitol. Sorbitol is then reduced to fructose by Sorbitol Dehydrogenase (SDH) coupled to transfer of electrons and protons to oxidized cytoplasmic Nicotinamide Adenine Dinucleotide $\left(N A D^{+} \mathrm{c}\right)$ to form NADHc, the reduced form of NAD. NADHc fuels production of superoxide by $\mathrm{NADHc}$-fueled $\mathrm{NAD}(\mathrm{P}) \mathrm{H}$ oxidases causing oxidative stress which impairs the activity of numerous enzymes including $\mathrm{Na}^{+} \mathrm{K}^{+} / \mathrm{ATP}$ ase resulting in Metabolic Suppression. Oxidative stress and Metabolic Suppression play key roles in mediating diabetic complications.

Future directions: This scenario has important implications for the design and optimization of future therapies for prevention and treatment of diabetic complications, e.g. endogenous antioxidants C-peptide and pyruvate and more efficacious inhibitors of sorbitol production and sorbitol oxidation.

1. Keywords: Diabetes; Oxidative stress; Metabolic suppression; Diabetic complications; Sorbitol oxidation

2. Abbreviations: AGEs: Advanced Glycation End products; Akt: Protein Kinase B (PKB); AR: Aldose Reductase; ARI: Aldose Reductase Inhibitor; DAG: DiacylGlycerol; ER: Endoplasmic Reticulum; GA3P: GlycerAldehyde 3-Phosphate; GA3P-DH: GlycerAldehyde 3-Phosphate Dehydrogenase; G3P: Glycerol 3-Phosphate; G3P-DHc: Cytosolic Glycerol 3-Phosphate Dehydrogenase; HIP: Hypoxic-Ischemic Preconditioning; GSIS: Glucose Stimulation of Insulin Secretion; IRS-1: Insulin Receptor Substrate-1; LDH: Lactate-DH: Lactate Dehydrogenase; L/P: Lactate/Pyruvate ratio; LVEDP: Left Ventricle End Diastolic Pressure; MG: Methylglyoxal; MPTP: Mitochondrial Permeability Transition Pore; $\mathrm{NAD}^{+} \mathrm{c}$ : Oxidized Cytosolic Nicotinamide Adenine Dinucleotide; NADHc: Reduced Cytosolic Nicotinamide Adenine Dinucleotide; $\mathrm{NADP}^{+} \mathrm{c}$ : Oxidized Cytosolic Nicotinamide Adenine Dinucleotide Phosphate; NADPHc: Reduced Cytosolic Nicotinamide Adenine Dinucleotide Phosphate; NEFA: NonEsterified Fatty Acids; NO: Nitric Oxide; NOX: NAD(P)H Oxidase; $\bullet \mathrm{O}_{2}$ : Superoxide; OSM: Online Supplemental Material; PARP: Poly(ADP-Ribose) Polymerase; ROS: Reactive Oxygen Species; RyR: Ryanodine Receptors; SERCA: Sarco(Endo)plasmic Reticulum $\mathrm{Ca}^{2+}$-ATPase; SDH: Sorbitol Dehydrogenase; SDI: Sorbitol Dehydrogenase Inhibitor; SOD: Superoxide Dismutase; Sorbitol-DH: Sorbitol Dehydrogenase

\section{Introduction}

Global awareness of the burgeoning societal and economic consequences of diabetes mellitus and its complications is expanding $[1,2]$. This includes recognition of the urgent need for more effective therapies for the prevention and treatment of diabetic complications [3]. Although the etiologies of diabetic vascular disease and neuropathy are currently under intensive investigation, the basic pathogenic mechanisms are not fully understood.

While insulinopenia [4,5], C-peptide deficiency [6-12], hyperlipidemia [13], and hypertension [14] all warrant intensive further investigation to clarify their roles in the development of diabetic complications, hyperglycemia per se has been implicated in playing a key role in the initiation and rate of progression of diabetic complications by numerous clinical studies, including the DCCT/EDIC [15] and the UKPDS (United Kingdom Prospective Diabetes Study) studies [16]. It is now widely agreed that hyperglycemia likely mediates/ exacerbates diabetic complications by causing oxidative stress [17], i.e. production of pro-oxidant in excess of anti-oxidant metabolites. Although hyperglycemia increases flux of glucose via glycolysis and via the sorbitol pathway, the relative importance of these 2 pathways and their contributions to oxidative stress remain controversial [18-32].

*Corresponding author: Joseph $\mathrm{R}$ Williamson, Department of Pathology Washington University School of Medicine, 1611 Kriste Court, St. Louis MO. 63131 USA, Tel: (314) 821-7137; Fax: (314) 821-4585; E-mail: jrw@pathology.wustl.edu

Received September 26, 2012; Accepted October 18, 2012; Published Octobe 24, 2012

Citation: Williamson JR, Ido Y (2012) Linking Diabetic Complications to Sorbito Oxidation, Oxidative Stress and Metabolic Suppression. J Diabetes Metab 3: 219. doi:10.4172/2155-6156.1000219

Copyright: @ 2012 Williamson JR, et al. This is an open-access article distributed under the terms of the Creative Commons Attribution License, which permits unrestricted use, distribution, and reproduction in any medium, provided the original author and source are credited. 
Sorbitol oxidation has been linked to the pathogenesis of both early and late complications in diabetic humans and animals. Aldose reductase, the enzyme that produces sorbitol from glucose, also has been shown to play a crucial role in inducing inflammatory biochemical reactions even in non-diabetic animals.

Increased sorbitol oxidation generates excess free cytosolic reduced 'pro-oxidant' $\mathrm{NADH}$ (NADHc) versus 'anti-oxidant' pyruvate. The resulting redox imbalance augments several metabolic pathways that re-oxidize NADHc to $\mathrm{NAD}^{+} \mathrm{c}$ and generate superoxide and associated metabolic imbalances linked to the pathogenesis of diabetic complications. Elevated NADHc levels augment superoxide production and related 'Reactive Oxygen Species' (ROS)] by NADHcfueled NAD $(\mathrm{P}) \mathrm{H}$ oxidases via several pathways. The resulting oxidative stress impairs the activity of numerous enzymes including $\mathrm{Na}^{+} / \mathrm{K}^{+}$ ATPase resulting in Metabolic Suppression; i.e. an adaptive response that prolongs cell viability by reducing ATP consumption balanced by decreased ATP synthesis. This allows ATP levels to remain constant even while ATP turnover rates greatly decline. This scenario has important implications for the design of future therapies for the prevention and treatment of diabetic complications.

The first enzyme of the sorbitol pathway is aldose reductase (EC. 1.1.1.21). It is present in kidney inner medulla, nerve, lens, testis and heart [33], and has been isolated from several tissues [34] including lens [35], placenta [36], renal medulla [37], and testis [38]. Genomic, structural, and enzymatic characteristics of the enzyme have been intensively studied, and aldose reductase has been shown to be a member of the aldo-keto reductase superfamily of enzymes [39]. Aldose reductase is designated as AKR1B1 (Aldo-Keto Reductase family 1 , member B1) in humans, which is also known as AR, ADR, ALR2, and ALDR1, and is coded on chromosome 7. In the Entrez Gene database, another closely related protein, i.e. AKR1B10, is frequently called aldose reductase like-peptide or small intestine reductase. These two enzymes differ in substrate specificity, but since they are more than $70 \%$ identical, some if not all antibodies cross-react with both proteins.

Aldose reductase (designated AKR1B3 in mice and AKR1B4 in rats) converts glucose to sorbitol with a $\mathrm{Km}$ of $\sim 60-100 \mathrm{mM}$. The high apparent $\mathrm{Km}$ for glucose is due to the fact that only the low abundance straight chain aldehyde form of glucose is a substrate; the $\mathrm{Km}$ for the straight chain form of glucose is $5 \mu \mathrm{M}$ [40]. Known regulators of glucose flux to produce sorbitol include: 1) intracellular glucose levels and 2) enzyme levels and activity. Flux activation in diabetes is largely attributable to increased glucose substrate levels evoked by hyperglycemia. However, in diabetes and inflammatory conditions transcriptional induction can also occur via inflammatory factor AP1, osmotic-responsive element (TonEBP/NFAT5), and Nrf2 [41]. In addition, the enzyme has been shown to be capable of undergoing post-translational cysteine-oxidation and glutathionylation [42]. Thus, depending on current specific circumstances, increased metabolic flux of glucose by aldose reductase may result from a combination of increased substrate availability, enzyme levels, and enzyme activity. Increased metabolic flux of glucose via aldose reductase and the second enzyme in the pathway, i.e. sorbitol dehydrogenase, is responsible for creating a pro-oxidant status which differs markedly from glycolytic metabolism discussed in Sections 4 and 5 below.

\section{Glucose Metabolism via Glycolysis: NADHc, Superoxide Production, and Oxidative Stress}

Nicotinamide-containing cofactors play fundamental roles in metabolism [43]. Free (unbound to enzymes/proteins) cytoplasmic
NADH (NADHc) occupies a central position in cytoplasmic and mitochondrial energy catabolism (Figure 1).

The ratio of free reduced NADHc to free oxidized $\mathrm{NAD}^{+} \mathrm{c}$ is the primary determinant of overall cellular redox status [44]. NADHc and $\mathrm{NAD}^{+} \mathrm{c}$ exist in dynamic equilibrium with other key metabolites, in particular with cytoplasmic lactate and pyruvate via the nearequilibrium catalyzed by Lactate Dehydrogenase (LDH). Equation 1 depicts the reversible oxidation of $\mathrm{NADHc}$ to $\mathrm{NAD}^{+} \mathrm{c}$ by $\mathrm{LDH}$ coupled to reduction of pyruvate to lactate that diffuses out of cells via monocarboxylic acid transporters which maintain equilibrium between intracellular and extracellular lactate/pyruvate ratios [45] (Figure 1).

$\mathrm{LDH}$

NADHc + Pyruvate $\leftrightarrow \mathrm{NAD}^{+} \mathrm{c}+$ Lactate

(Equation 1)

$\mathrm{NAD}(\mathrm{P}) \mathrm{H}$ oxidases

$\mathrm{NADHc}+\mathrm{O}_{2} \rightarrow \mathrm{NAD}^{+} \mathrm{c}+\bullet \mathrm{O}_{2}$

(Equation 2)

However, when the rate of glycolysis is markedly increased, e.g. by hypoxia or strenuous exercise, lactate is produced faster than it is removed at resting tissue blood flows. The resulting increased lactate levels can drive the $\mathrm{LDH}$ reaction in the reverse direction resulting in oxidation of lactate to form 'antioxidant' pyruvate and equimolar 'prooxidant' NADHc.

In this circumstance, $\mathrm{NAD}^{+} \mathrm{c}$ needed for continued glycolysis also can be regenerated from 'pro-oxidant' NADHc by NAD(P)Hc-fueled

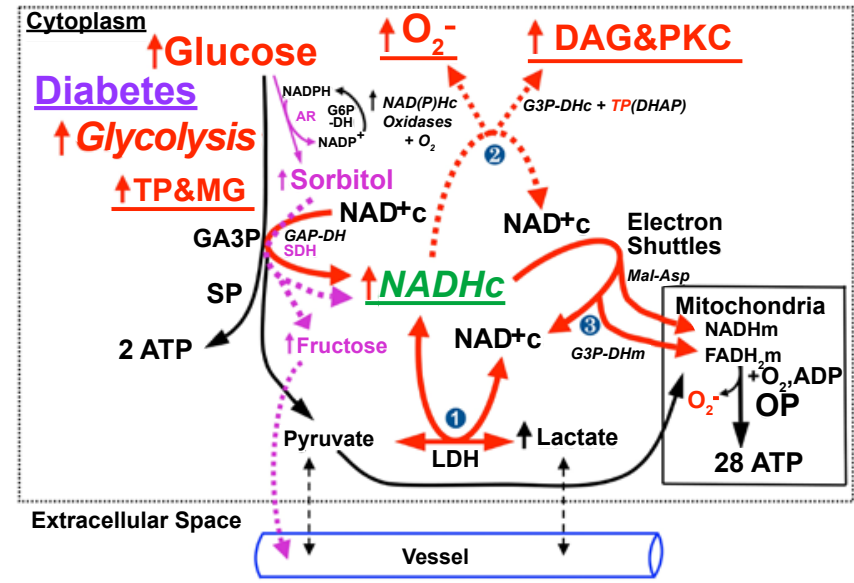

Figure 1: Key roles of increased cytosolic NADHc produced by sorbito oxidation in fueling superoxide formation and related metabolic pathways linked to the pathogenesis of diabetic complications.

The percentage increase in sorbitol oxidation in normal rat retinas and endoneuria incubated in 30 vs. $5 \mathrm{mM}$ glucose (manifested by production of fructose equimolar to NADHc) exceeds the percent increase in glycolysis (manifested by lactate production) $[27,80]$

Since oxidation of sorbitol does not form pyruvate, NADHc levels rise $\sim 1.5$-2-fold (manifested by increased ratios of $\mathrm{NADH} / \mathrm{NAD}^{+} \mathrm{C}=$ lactate/pyruvate $\times \mathrm{K}_{\mathrm{LHH}}$ ) [44], fructose levels increase ( 10-30-fold), and much more $\mathrm{NADHc}$ is reoxidized to $\mathrm{NAD}^{+} \mathrm{c}$ via alternative pathways, i.e. by $\mathrm{NADHc}$-fueled $\mathrm{NAD}(\mathrm{P}) \mathrm{H}$ oxidases that increase superoxide production and by G3P-DHc which increases synthesis of diacylglycerol (DAG) [25-57] which activates protein kinase $C$ (PKC) that activates NADPH-driven oxidases to further augment superoxide production.

The $\sim 1.5$-2-fold increases in NADHc also contribute to product inhibition of GA3P-DH, which increases levels of GA3P and DHAP, i.e. triose phosphatesTPs, [25] that are in equilibrium. Non-enzymatic degradation of DHAP and GA3P forms methylglyoxal (MG), a precursor of advanced glycation endproducts (AGEs) that impair the activity of numerous enzymes including GA3P$\mathrm{DH}[25,61,62]$. 
oxidases coupled to production of superoxide (Equation 2). Pyruvate formed by oxidation of lactate (Equation 1) may be transported into mitochondria to fuel ATP synthesis or diffuse out of the cell via monocarboxylic acid transporters that maintain near-equilibrium between intracellular and extracellular lactate/pyruvate ratios as noted above [45] (Figure 1) and equation 4.

The near-equilibrium between intracellular molar ratios of (unbound to proteins/enzymes) forms of $\mathrm{NAD}^{+} \mathrm{c} / \mathrm{NADHc}=$ pyruvate/ lactate maintained by $\mathrm{LDH}$ (equilibrium constant $\mathrm{K}_{\mathrm{LDH}}=1.11 \times 10^{-4}$ at $\mathrm{pH} 7.0$ ) is depicted in equation 3 [44], and inversely as in equation 4.

$$
\begin{aligned}
& \mathrm{NAD}^{+} \mathrm{c} / \mathrm{NADHc}=\text { Pyruvate } / \text { Lactate } \times 1 / \mathrm{K}_{\mathrm{LDH}} \\
& \mathrm{NADHc} / \mathrm{NAD}^{+} \mathrm{c}=\text { Lactate } / \text { Pyruvate } \times K_{\mathrm{LDH}}
\end{aligned}
$$$$
\text { (Equation 3) }
$$

In a wide range of normal tissues and cells molar ratios of $\mathrm{NADHc} /$ $\mathrm{NAD}^{+} \mathrm{C}$ and lactate/pyruvate in equation 4 are $\sim 1 / 1000$ and $\sim 10 / 1$, respectively [25]. At equilibrium there is typically only $\sim 1$ mole of $\mathrm{NADHc}$ per 1,000 moles of $\mathrm{NAD}^{+} \mathrm{c}$. Thus molar changes in NADHc have a far greater impact on both ratios in equation 4 than equimolar changes in $\mathrm{NAD}^{+}$, lactate, or pyruvate. An increase of only 1 additional mole of unbound $\mathrm{NADHc}$ will double $\mathrm{NADH} / \mathrm{NAD}^{+} \mathrm{c}=$ lactate/ pyruvate $\times K_{\mathrm{LDH}}$ ratios that are typically increased $\sim 1.5$ to 2 -fold by diabetes, hypoxia, and increased physiological work in numerous tissues in humans and animals, e.g. retina, nerves, brain, and muscles, that are associated with increased blood flows $[25,46]$.

These observations suggest that NADHc 1) is an exquisitely sensitive redox metabolite sensor of product inhibition GA3P-DH and 2) elevated NADHc levels fuel a) superoxide production (by NADHcfueled $\mathrm{NAD}(\mathrm{P}) \mathrm{Hc}$ oxidases coupled to reoxidation of $\mathrm{NADHc}$ to $\mathrm{NAD}^{+} \mathrm{c}$ (Equation 2)) and b) redox signaling pathways that augment blood flow evoked by hyperglycemia, physiological work, and hypoxia in numerous tissues [46].

The significance of very high ratios of oxidized $\mathrm{NAD}^{+} \mathrm{c}$ to reduced $\mathrm{NADHc}$ has been widely thought to ensure that $\mathrm{NAD}^{+} \mathrm{c}$ levels are not rate limiting for GA3P-DH activity requisite for ATP synthesis from glucose via glycolysis (Figure 1). In addition, we suggest very low levels of NADHc restrain product inhibition of GA3P-DH and associated sequelae, e.g. impaired ATP synthesis, elevated levels of triose phosphates (TP), etc. [25] (Figure 1).

Equations 3 and 4 have very important, albeit not widely appreciated, implications for potential misinterpretation of observations in cells and tissues incubated in relatively small volumes of media in vitro. Accumulation of lactate in the incubation medium is a major confounding factor in interpreting metabolic effects of elevated glucose levels in cells and tissues in vitro. This can result in accumulation of high levels of intracellular and extracellular lactate produced by glycolysis, marked increases in $\mathrm{NADH} / \mathrm{NAD}^{+} \mathrm{c}=$ lactate/ pyruvate $\times K_{\mathrm{LDH}}$ ratios, and increased intracellular levels of triose phosphates like those evoked by hyperglycemia, sorbitol oxidation, hypoxia, and physiological work as demonstrated by observations of Tilton et al. [47] and summarized by Nyengaard et al. [27].

To avoid misinterpretation of observations in such experiments, it is essential to assess lactate/pyruvate ratios in the incubation medium and (when feasible) in the incubated cells and tissues as well. Tilton et al. [47], reported that when normal human erythrocytes were incubated in $3 \mathrm{ml}$ of culture medium (at a 33\% Hct) in a dialysis bag containing 2.5 $\mathrm{mM}$ glucose for $3 \mathrm{~h}, \mathrm{NADH} / \mathrm{NAD}^{+} \mathrm{c}=$ lactate/pyruvate ratios increased $\sim 6$-fold (from $\mathrm{L} / \mathrm{P}=9$ at baseline to $\mathrm{L} / \mathrm{P}=57$ ) and triose phosphate levels increased over 10 -fold (from 36 to $538 \mu \mathrm{mol} / \mathrm{l} / \mathrm{gHb}$ ). Both increases were prevented when the dialysis bag was suspended in a 10-fold larger volume of incubation medium. The importance of these observations is attested to by observations of Nyengaard et al. in retina [27] and in sciatic nerve endoneurium [25] from normal rats incubated in vitro in hyperglycemic media \pm hypoxia. Aldose Reductase Inhibitors (ARI) selectively prevented increases in $\mathrm{NADH} / \mathrm{NAD}^{+} \mathrm{c}=$ lactate/pyruvate $\times K_{\mathrm{LDH}}$ ratios, lactate production, and triose phosphates evoked by hyperglycemia, but did not prevent corresponding concurrent increases evoked by hypoxia.

In view of these observations, it is noteworthy that Nishikawa et al. [26] did not assess lactate or pyruvate levels in incubated Bovine Aortic Endothelial Cells (BAEC) or in the incubation medium in their experiments on the effects of inhibition of pyruvate transport into mitochondria. And, although sorbitol levels were increased $~ 3$ fold, Nishikawa et al. [26] also did not assess effects of ARI or Sorbitol Dehydrogenase (SDI) on increased superoxide production that might have prevented or attenuated superoxide produced by oxidation of $\mathrm{NADHc}$ (generated by sorbitol oxidation) by NAD(P)H oxidases in the cytoplasm rather than by mitochondrial oxidation of pyruvate. The conclusion of Nishikawa et al. [26] that blocking pyruvate transport into mitochondria prevented increased ROS production also is discordant with 1) observations published by earlier investigators that blocking pyruvate transport into mitochondria markedly decreased NADH/ $\mathrm{NAD}^{+} \mathrm{c}=$ lactate/pyruvate $\times K_{\mathrm{LDH}}$ ratios in perfused hearts from normal rats and guinea pigs and increased pyruvate release from epididymal fat pads and guinea pig hearts [27] and 2) antioxidant effects of pyruvate supplementation discussed below in Section 5.1. Important caveats to interpretations of effects of other pharmacological agents in the experiments of Nishikawa et al. [26] are also addressed by Nyengaard et al. [27]

\section{Glucose Metabolism via the Sorbitol Pathway: Sorbitol Oxidation, NADHc, and Oxidative Stress}

Hyperglycemia significantly increases glucose metabolism via the sorbitol pathway as well as via glycolysis. Aldose reductase (E.C. 1.1.1.21, encoded by the $A K R 1 B 1$ gene, abbreviated here as "AR"), catalyzes transfer of a hydride ion (two electrons and a proton) from free cytoplasmic NADPH (NADPHc) to glucose coupled to reduction of glucose to sorbitol and oxidation of NADPHc to $\mathrm{NADP}^{+} \mathrm{c}$ [25] as in equation 5 .

\section{Aldose Reductase}

Glucose + NADPHc $+\mathrm{H}^{+} \rightarrow$ Sorbitol $+\mathrm{NADP}^{+} \mathrm{c}$

(Equation 5)

Sorbitol is then oxidized to fructose by Sorbitol Dehydrogenase (SDH). This reaction is coupled to transfer of a hydride ion from sorbitol to $\mathrm{NAD}^{+} \mathrm{c}$, which is reduced to NADHc equimolar to fructose (Equation 6). However, in contrast to production of NADHc via glycolysis, NADHc formed by sorbitol oxidation is uncoupled from downstream production of equimolar 'antioxidant' pyruvate requisite for reoxidation of $\mathrm{NADHc}$ to $\mathrm{NAD}^{+} \mathrm{c}$ by $\mathrm{LDH}$ (Equation 1) coupled to reduction of pyruvate to lactate that diffuses out of the cell. As a consequence, NADHc levels increase and (like increased NADHc levels evoked by hypoxia) fuel superoxide production by $\mathrm{NAD}(\mathrm{P}) \mathrm{H}$ oxidases coupled to reoxidation of NADHc to $\mathrm{NAD}^{+} \mathrm{c}$ (Equation 2). We refer to the hypoxia-like increase in NADHc levels produced by sorbitol oxidation as "Hyperglycemic Pseudohypoxia" [46]

$\mathrm{SDH}$

Sorbitol $+\mathrm{NAD}^{+} \mathrm{c} \rightarrow$ Fructose $+\mathrm{NADHc}+\mathrm{H}^{+}$

(Equation 6) 
Thus increased flux of glucose via the sorbitol pathway promotes: a) oxidation of NADPHc to $\mathrm{NADP}^{+} \mathrm{c}$ in the first step and b) reduction of $\mathrm{NAD}^{+} \mathrm{c}$ to 'pro-oxidant' $\mathrm{NADHc}$ and equimolar fructose (sans equimolar 'anti-oxidant' pyruvate) in the second step (See Antioxidant effects of pyruvate in Section 5.1)

Some investigators have speculated that decreased levels of reduced glutathione (GSH) in tissues of diabetic animals (e.g. peripheral nerves, retina, and lens) may be due to decreased availability of NADPH because of increased utilization of NADPH by aldose reductase. However, as emphasized by Obrosova [29]: "Diabetes-related depletion of NADPH has never been documented in diabetic kidney, peripheral nerve, heart, and retina." Furthermore, we demonstrated that NADPHc/NADP ${ }^{+} \mathrm{c}$ ratios were increased in parallel with increased $\mathrm{NADH} / \mathrm{NAD}^{+} \mathrm{c}=$ lactate/ pyruvate $\times K_{\mathrm{LDH}}$ ratios [25]. This finding is consistent with observations in other studies that NADPH levels are increased in peripheral nerve and lens of diabetic rats' lens [25].

In cells that do not require insulin for glucose uptake, hyperglycemia augments sorbitol oxidation generation of excess NADHc (Equations 5 and 6); excess NADHc fuels superoxide production by NADHcdriven oxidases (Equation 2) $[48,49]$ and other enzymes linked to the pathogenesis of diabetic complications (Figure 1). This scenario predicts: 1) exposure of normoglycemic cells and tissues to elevated sorbitol levels might mimic effects of hyperglycemia on superoxide production and associated metabolic imbalances and tissue dysfunction/damage and 2) potent inhibitors of Sorbitol dehydrogenase (SDI) should be comparably efficacious in preventing metabolic imbalances and tissue dysfunction/damage evoked by elevated glucose levels or elevated sorbitol during normoglycemia. 3) In contrast, metabolic imbalances and tissue dysfunction/damage evoked in tissues exposed to elevated sorbitol levels during normoglycemia should be prevented by inhibitors of SDI but not by ARI.

Predictions land 3 have been confirmed by numerous observations in normoglycemic cells and tissues exposed to elevated sorbitol levels in vivo and in vitro [25]. These effects of sorbitol also are prevented or substantially attenuated by addition of exogenous 'antioxidant' pyruvate and by superoxide dismutase (SOD) [25].

Prediction 2 also has been confirmed by observations that ARI and SDI normalize impaired motor nerve conduction velocity (MNCV) and associated increased blood flows and vascular permeability in sciatic nerve and retina in rats with diabetes of 18-weeks of diabetes [25]. Both inhibitors also prevented an accompanying 1.9-fold increase in sciatic nerve $\mathrm{NADHc} / \mathrm{NAD}^{+} \mathrm{c}$ ratios, but had no impact on the associated $\sim 1.6$-fold increase in mitochondrial NADHm $/ \mathrm{NAD}^{+} \mathrm{m}$ (Figure 2). (The increase in $\mathrm{NADHm} / \mathrm{NAD}^{+} \mathrm{m}$ may be explained by increased oxidation of fatty acids and ketones, plasma levels of which were significantly elevated and unaffected by ARI or SDI [25] (Figure 2).

Observations that inhibition/attenuation of sorbitol oxidation by pyruvate and by SOD (as well as by ARI and SDI) normalized impaired vascular and neural dysfunction and increased $\mathrm{NADHc} /$ $\mathrm{NAD}^{+} \mathrm{c}$ ratios evoked by hyperglycemia, but had no impact on increased $\mathrm{NADHm} / \mathrm{NAD}^{+} \mathrm{m}$ ratios [25] are inconsistent with the hypothesis of Brownlee and Nishikawa et al. $[18,26]$ for the primacy of increased intra-mitochondrial oxidation of pyruvate (generated by increased glycolysis) in fueling hyperglycemia-induced oxidative stress and metabolic imbalances implicated in the pathogenesis of diabetic complications [25]. These observations also are discordant with the speculation by Giacco and Brownlee [22] that "glucose does not appear to be the substrate for the enzyme aldose reductase because the $K_{\mathrm{m}}$ of

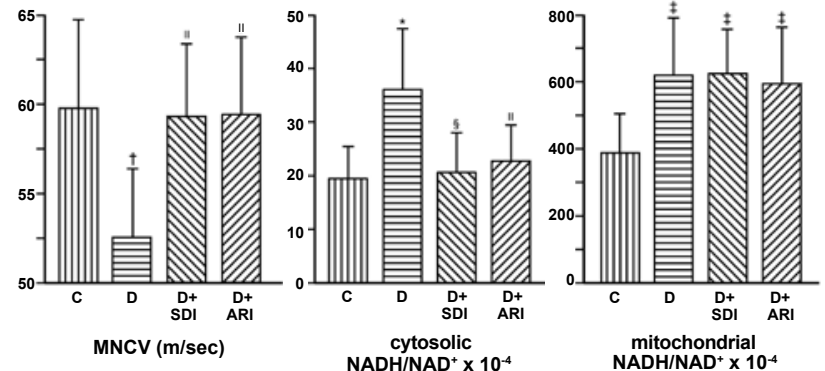

Figure 2: Effects of the SDI-CP-166,572 (200 mg/kg bwt/day) and the ARI Sorbinil ( $50 \mathrm{mg} / \mathrm{kg}$ bwt/day) on distal tibial MNCV and on sciatic nerve NADH/ $\mathrm{NAD}^{+} \mathrm{C}$ and $\mathrm{NADH} / \mathrm{NAD}^{+} \mathrm{m}$ in rats with diabetes of 18 weeks duration.

Means $\pm S D(N=9-12$ rats for all parameters)

Different from Controls: ${ }^{*} P<0.001 ;{ }^{\dagger} P=0.005 ;{ }^{\ddagger} P<0.02$;

Different from Diabetics: ${ }^{\S} P<0.02$; $P=0.05$ [25]

aldose reductase for glucose is $100 \mathrm{mmol} / \mathrm{l}$, whereas the intracellular concentration of glucose in diabetic endothelial cells is $30-\mathrm{nmol} / \mathrm{mg}$ protein." This speculation was not supported by credible evidence and is refuted by observations of Ido et al. [25] Additional caveats to other speculative interpretations of observations of Brownlee et al. [18] are addressed below and in Section 10.

Important caveats to the hypothesis of Nishikawa et al. [26] for the primacy of increased intra-mitochondrial oxidation of pyruvate (generated by increased glycolysis) in fueling hyperglycemia-induced oxidative stress and sequelae implicated in the pathogenesis of diabetic complications are addressed by Ido et al. [25]. Of particular interest and importance are the observations that exposure of normal human erythrocytes (that lack nuclei and mitochondria) to elevated glucose levels or to increased sorbitol levels at normal glucose levels evoke increased $\mathrm{NADHc} / \mathrm{NAD}^{+} \mathrm{c}$ ratios etc. that are prevented/attenuated by addition of pyruvate and/or inhibitors of aldose reductase [25]. Conclusions of Obrosova et al. [50-52] that sorbitol oxidation is not a significant contributor to oxidative stress and metabolic imbalances evoked by diabetes are attributable to speculations not supported by credible evidence and by major caveats to experimental protocols addressed by Nyengaard et al. [27] and Ido et al. [25].

Conclusions of Cameron et al. [19,53] that SDI lack efficacy and that decreased MNCV is caused by decreased blood flow-ischemia are explained by major caveats to experimental protocols addressed by Chang et al. [54], Ido et al. [55,25], Nyengaard et al. [27]. Briefly, decreased nerve blood flows in diabetic rats reported by Cameron et al $[19,53]$ appear to be largely attributable to 1 ) surgical exposure of nerves before measurement of blood flow and 2) use of indirect methods to assess blood flow [25]. Surgical exposure markedly increases blood flows in nerves of normal rats, but not in diabetic rats. The decreased blood flows in surgically exposed nerves of diabetic rats are consistent with: 1) impaired redox signaling pathways that augment blood flow evoked by mild trauma and inflammation as demonstrated by Ido et al. [25] and 2) Metabolic Suppression mediated by impaired $\mathrm{Na}^{+} / \mathrm{K}^{+}$ ATPase activity discussed below in Section 6.

Blood flows and vascular albumin permeation in retina and in unexposed nerves of diabetic rats are significantly increased by diabetes of relatively short duration, e.g. 5 weeks, and are normalized by ARI and SDI [25] and by C-peptide [12]. With increasing duration and severity of diabetes neural blood flows are comparable to, or decreased, compared to nondiabetic rats. These observations are consistent with 
evidence that inhibitors of aldose reductase protect hearts of Type 1 diabetic rats and hearts of nondiabetic controls from ischemic injury [32]; both ARI and SDI reduce ischemia-reperfusion injury (and associated increases in $\mathrm{NADHc} / \mathrm{NAD}^{+} \mathrm{c}$ ratios manifested by increased lactate/pyruvate ratios) to hearts from Type 2 diabetic BBZ rats [56].

The beneficial effects of antioxidant pyruvate in preventing increased superoxide production evoked by elevated levels of sorbitol and hyperglycemia are discordant with the hypothesis of Brownlee and Nishikawa et al. $[18,26]$ that increased production of pyruvate via glycolysis (evoked by hyperglycemia) fuels increased superoxide production in mitochondria and is the major cause of oxidative stress evoked by hyperglycemia. However, beneficial antioxidant effects of pyruvate are consistent with observations of numerous investigators as discussed below and by Ido et al. [25].

\subsection{Antioxidant effects of pyruvate}

An important key to understanding how pyruvate supplementation attenuates superoxide production and associated metabolic imbalances evoked by increased sorbitol oxidation is the difference in end products of glucose metabolized via glycolysis versus sorbitol oxidation.

Before glucose can be utilized for ATP synthesis (by substrate phosphorylation in the cytoplasm or by oxidative phosphorylation in mitochondria) electrons and protons must first be transferred from Glyceraldehyde 3-Phosphate (GA3P) by GA3P-DH coupled to reduction of $\mathrm{NAD}^{+} \mathrm{c}$ to 'pro-oxidant' $\mathrm{NADHc}$. This reaction is followed by downstream formation of 'anti-oxidant' pyruvate equimolar to pro-oxidant NADHc (Figure 1). Normoxic normoglycemic resting cells generate NADHc and pyruvate faster than they are utilized for ATP synthesis and other reactions. Excess NADHc and pyruvate are recombined by lactate- $\mathrm{DH}$ to form lactate, which exits cells via monocarboxylate transporters and is removed from the tissue by blood vessels [45] (Figure 1).

As shown in Equation 2, oxidation of sorbitol to equimolar fructose by sorbitol-DH is coupled to transfer of electrons and protons from oxidized $\mathrm{NAD}^{+} \mathrm{c}$ to $\mathrm{NADHc}$ that is uncoupled from subsequent production of pyruvate required for reoxidation of $\mathrm{NADHc}$ to $\mathrm{NAD}^{+} \mathrm{C}$ by lactate-DH (Figure 1). Thus NADHc levels increase (manifested by $\sim 1.5$ to 2 -fold increased ratios of reduced to oxidized NADHc/ $\mathrm{NAD}^{+} \mathrm{c}$ ). Increased levels of NADHc augment superoxide production by NADHc-fueled $\mathrm{NAD}(\mathrm{P}) \mathrm{H}$ oxidases [25] in numerous tissues (Equation 3 and Figure 1).

It has been suggested that increased oxidative stress evoked by hyperglycemia is largely attributable to decreased availability of NADPH (due to increased consumption of NADPH by aldose reductase (Equation 5) needed to maintain antioxidant GSH (reduced glutathione) levels. However, this speculation is discordant with 1) observations of Ido et al. that both NADPH/NADP ${ }^{+} \mathrm{c}$ and NADH/ $\mathrm{NAD}^{+} \mathrm{c}$ ratios were increased by diabetes and were normalized by SDI [25] and 2) observations of other investigators [25].

Brownlee maintains: "Although hyperglycemia does increase the $\mathrm{NADH}: \mathrm{NAD}^{+}$ratio in endothelial cells, this reflects a marked decrease in the absolute concentration of $\mathrm{NAD}^{+}$as a result of consumption by activated poly(ADP-ribose) polymerase (PARP) rather than enzymatic reduction by $\mathrm{SDH}$ of $\mathrm{NAD}^{+}$to $\mathrm{NADH}$ [18]." This assertion is inconsistent with observations of numerous investigators summarized by Ido et al. [25].

Attenuation of adverse effects of hyperglycemia and elevated sorbitol levels by pyruvate supplementation is consistent with its well-known antioxidant effects that prevent or markedly attenuate metabolic imbalances, vascular dysfunction, and tissue damage evoked by hypoxia/ischemia in humans and animals [25]. Pyruvate is one of the most potent agents assessed for preventing opening of Mitochondrial Permeability Transition pores (MTPT) and associated ischemia-reperfusion injury [57-60]. Pyruvate supplementation increases the threshold for the severity of ischemia required to evoke preconditioning in globally ischemic rat hearts [60].

Pyruvate 1) stoichiometrically degrades superoxide $\left(\bullet \mathrm{O}_{2}^{-}\right)$to $\mathrm{H}_{2} \mathrm{O}$ and peroxynitrite coupled to non-enzymatic oxidative decarboxylation of pyruvate to acetate [25] and, perhaps more importantly, 2) prevents - $\mathrm{O}_{2}$ - production by $\mathrm{NADHc}$-fueled $\mathrm{NAD}(\mathrm{P}) \mathrm{H}$ oxidases by driving reoxidation of NADHc to $\mathrm{NAD}^{+} \mathrm{c}$ by lactate-DH coupled to reduction of pyruvate to lactate that diffuses out of the cell [45] (Figure 1).

The second mechanism may be especially important since pyruvate supplementation, like ARI, could prevent product inhibition of GA3PDH activity (by elevated NADHc levels) and associated increased Triose Phosphate (TP) levels that include (GA3P) and DiHydroxyAcetone Phosphate (DHAP) that are maintained in equilibrium by Triose Phosphate Isomerase (TPI) as depicted in Figure 1. In normal rat retinas and endoneuria incubated in vitro, ARI prevented increased TP and NADHc levels evoked by hyperglycemia, but did not attenuate associated increases in glycolysis; manifested by increased lactate production $[25,27]$

Increased levels of DHAP and NADHc drive reduction of DHAP to G3P by G3P-DHc coupled to reoxidation of NADHc to $\mathrm{NAD}^{+} \mathrm{c}$ (Figure 1), the first step in one pathway for de novo synthesis of DAG. Increased levels of DAG activate PKC which, in turn, activates some isoforms of $\mathrm{NAD}(\mathrm{P}) \mathrm{H}$-driven oxidases that further augment superoxide production. Although Giacco and Brownlee [22] commented that increased GA3P levels activate the classic PKC pathway by increasing DAG levels, they did not address the important role of NADHc in fueling the reactions that generate DAG and activation of PKC (Figure $1)$.

ARI also prevent increased TP levels and lactate/pyruvate $=\mathrm{NADH} /$ $\mathrm{NAD}^{+} \mathrm{C} \times K_{\mathrm{LDH}}$ ratios in normal rat sciatic nerve endoneuria [25] and retinas [27] incubated in 30 vs. $5 \mathrm{mM}$ glucose. In addition, pyruvate supplementation, like ARI, prevents increased TP levels evoked by elevated glucose levels in erythrocytes (that lack nuclei and mitochondria) from normal humans [25] and in incubated retinas from normal rats [25]; lastly), in vivo pyruvate supplementation prevents increased DAG levels in granulation tissue exposed to topical hyperglycemia in non-diabetic rats [25].

GA3P and DHAP also undergo concentration-dependent nonenzymatic degradation to form methylglyoxal (Figure 1), a potent non-enzymatic glycating agent that forms Advanced Glycation Endproducts (AGEs). AGEs impair the activity of many enzymes including GA3P-DH [61,62]. Although potentially important consequences of product inhibition of GA3P-DH activity have not been widely investigated, it is noteworthy that impairment of GA3P-DH activity via product inhibition by increased NADHc levels may develop more rapidly during transient postprandial hyperglycemia and may also be reversed more readily than impaired GA3P-DH activity caused by chemical modification by superoxide and related ROS, etc. evoked by chronic hyperglycemia, hypoxia, or strenuous physical activity [63-65]

Investigators reporting beneficial effects of $\alpha$-lipoic acid in diabetic humans and animals rarely draw attention to the fact that antioxidant 
a-lipoic acid, like antioxidant pyruvate 1) scavenges ROS and 2) reoxidizes $\mathrm{NADHc}$ to $\mathrm{NAD}^{+} \mathrm{c}$ (coupled to reduction of $\alpha$-lipoate to dihydrolipoate) thereby depriving NADHc-fueled NAD $(\mathrm{P}) \mathrm{H}$ oxidases of fuel for generating superoxide [30,64-67]. a-lipoic acid substantially 1) decreases cytosolic $\mathrm{NADH} / \mathrm{NAD}^{+} \mathrm{c}$ (manifested by significantly decreased lactate/pyruvate ratios as in equation 4) and 2) attenuates vascular dysfunction and neuropathy in diabetic humans and animals, cataract formation in diabetic animals, etc.

\subsection{Disappointing outcomes of clinical trials with aldose reductase inhibitors}

Metabolism of excess intracellular glucose via the sorbitol pathway has long been suspected of contributing to diabetic complications [68]. Worldwide efforts over the last four decades to develop Aldose Reductase Inhibitors (ARIs) have focused on pharmacologically inhibiting production of sorbitol by aldose reductase. Although the impact of ARIs on diabetic complications in numerous clinical trials has been generally disappointing $[28,69]$, two key insights have emerged from preclinical and clinical studies. First, beneficial effects of ARIs in most tissues likely result primarily from normalization of prooxidant NADHc levels and oxidative stress fueled by increased sorbitol oxidation (Equation 5) [20,25].

Second, ARI doses needed to normalize nerve sorbitol levels produced by aldose reductase are substantially higher (3-18-fold) than are required to normalize downstream metabolites such as fructose (produced by sorbitol oxidation equimolar to $\mathrm{NADHc}$ ) and the oxidative stress biomarker GSSG/GSH ), $[20,25,28]$. These new insights strongly suggest the disappointing efficacy of ARIs in clinical trials to date are largely due to underdosage of ARIs that were inadequate to normalize sorbitol, fructose, and NADHc levels and associated oxidative stress. Stronger inhibition of aldose reductase (Equation 5) is required to reduce downstream production of NADHc and superoxide generation than to reduce sorbitol levels.

6. Increased Sorbitol Oxidation Impairs $\mathrm{Na}^{+} / \mathrm{K}^{+}$ ATPase Activity in Many Tissues, Resulting in Metabolic Suppression, Insulin Resistance, $\beta$-Cell Dysfunction, and Increased Resistance to Hypoxic/ Ischemic Injury. Increased Plasma Non-Esterified Fatty Acid (NEFA) Levels in Exercising Rats also Impair $\mathrm{Na}^{+} / \mathrm{K}^{+}$-ATPase Activity and Increase Resistance to Hypoxic/Ischemic Injury

Hochachka et al. [70-72] characterize 'Metabolic Suppression' as an adaptive response to hypoxia/ischemia -and we suggest to 'Hyperglycemic pseudohypoxia' [46] that prolongs cell viability by reducing ATP consumption balanced by decreased ATP synthesis. Impaired $\mathrm{Na}^{+} / \mathrm{K}^{+}$-ATPase activity consumes less ATP that is balanced by a corresponding decrease in the rate of ATP synthesis, which allows ATP levels to remain constant even while ATP turnover rates greatly decline (Figure 3) as discussed in Section 6a (Figure 3).

These beneficial effects of relatively mild Metabolic Suppression are consistent with the beneficial effects of briefly exposing normal cells and tissues to relatively mild hypoxia-ischemia which increases their resistance to more serious dysfunction evoked by subsequent exposure to more severe hypoxia-ischemia, i.e. 'Hypoxic-ischemic preconditioning (HIP)' in nondiabetics.

6a. The ouabain-inhibitable fraction of $\mathrm{Na}^{+} / \mathrm{K}^{+}$-ATPase, manifested by decreased ${ }^{86} \mathrm{Rb}^{+}$uptake as an indicator of $\mathrm{K}^{+}$-pump activity, is impaired by diabetes in numerous cells and tissues in humans and animals including: peripheral nerve [11,73-78], retina [79-83], lens $[84,85]$, heart $[76,86,87]$, skeletal muscle $[76,88]$, arteries [89-94], erythrocytes $[6,7,77,95,96]$, platelets [95], pancreatic beta cells in obese (ob/ob) mice [97], and kidney [96,98].

Numerous observations suggest that insulin resistance, i.e. impaired insulin-dependent stimulation of glucose utilization, may be a consequence (at least in part) of Metabolic Suppression caused by oxidative stress evoked by increased oxidation of sorbitol and/or NonEsterified Fatty Acids (NEFA). The importance of elevated NEFA levels

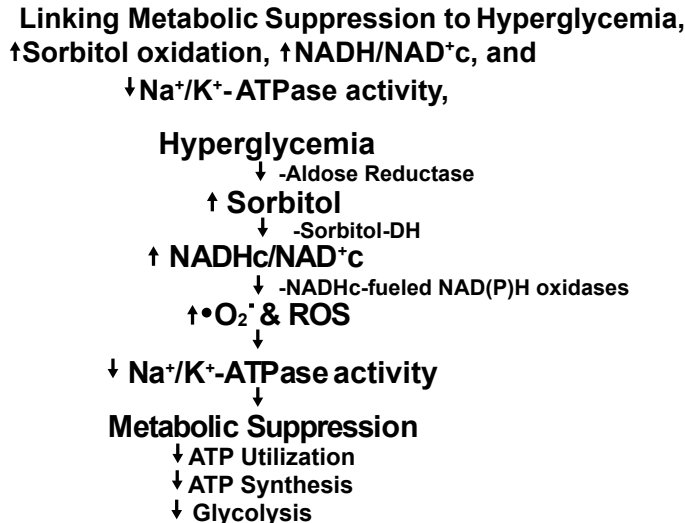

Figure 3: Sorbitol oxidation, Oxidative stress, impaired $\mathrm{Na}^{+} / \mathrm{K}^{+}$-ATPase activity, elevated plasma NEFA levels: links to Insulin Resistance and Metabolic suppression manifested by decreased glucose utilization, impaired ATP synthesis, and decreased glycolysis.

Increased levels of reduced NADHc 1 ) fuel production of superoxide $\left(\bullet^{-}{ }^{-}\right)$and related Reactive Oxygen Species (ROS) by NADHc-fueled NAD(P)H oxidases coupled to reoxidation of $\mathrm{NADHc}$ to $\mathrm{NAD}^{+} \mathrm{C}$ and 2) increase triose phosphates, including DHAP which is reduced to G3P by G3P-DH coupled to reoxidation of $\mathrm{NADHc}$ to $\mathrm{NAD}^{+} \mathrm{c}$, the first step in one pathway for de novo synthesis of diacylglycerol (DAG) that activates PKC which, in turn, activates some isoforms of $\mathrm{NAD}(\mathrm{P}) \mathrm{H}$-driven oxidases that further augment superoxide production (Figure 1).

Increased superoxide and ROS impair $\mathrm{Na}^{+} / \mathrm{K}^{+}$-ATPase activity which preferentially limits utilization of ATP by numerous enzymes and metabolic pathways not crucial for sustaining viability while selectively maintaining utilization of ATP by enzymes and metabolic pathways vital for sustaining viability, e.g. $\mathrm{Na}^{+} / \mathrm{K}^{+}$-ATPase activity which maintains high intracellular ratios of $\mathrm{K}^{+} / \mathrm{Na}^{+}$versus high extracellular ratios of $\mathrm{Na}^{+} / \mathrm{K}^{+}$. These changes result in decreased overall rates of ATP utilization, ATP synthesis, and glycolysis, i.e. Metabolic Suppression, consistent with the hypothesis of Hochachka [70-72] and beneficial effects of Hypoxic/lschemic Preconditioning (HIP).

Utilization of glucose by insulin-sensitive tissues in type 2 diabetics, e.g. skeletal muscle, liver, fat cells, etc. requires binding of insulin to cell surface receptors followed by tyrosine phosphorylation of IRS-1 which mediates insulin effects on glucose metabolism [100]. Phosphorylation of IRS-1 is significantly impaired in obese nondiabetic subjects and in type 2 diabetics resulting in insulin resistance [100]. Intravascular infusion of NEFA in nondiabetics to reproduce plasma NEFA levels in type 2 diabetes also causes muscle and liver insulin resistance and inhibits insulin secretion: "the 3 basic core metabolic defects in type 2 diabetes" [100]

DeFronzo [100] attributes insulin resistance in muscle and liver in type 2 diabetics primarily to sequelae of impaired phosphorylation of tyrosine residues on the beta chain of IRS-1 causing downstream impairment of glucose metabolism in numerous tissues. We suggest this impairment of glucose metabolism is consistent with Metabolic Suppression, i.e. $\downarrow$ ATP utilization, $\downarrow$ ATP synthesis, and $\downarrow$ glycolysis. This scenario is consistent with downregulation of enzymatic reactions that utilize ATP for phosphorylation of IRS-1 and other reactions not crucial for maintaining cell viability 'in the short term'. This scenario also is consistent with Metabolic Suppression evoked by hypoxia (and, we suggest, 'Hyperglycemic pseudohypoxia' [46]), and beneficial effects of hypoxic/ischemic preconditioning (HIP). 
is supported by observations cited by DeFronzo $[99,100]$ that infusion of sufficient NEFA in non-diabetics to achieve NEFA levels similar to those in type 2 diabetes causes muscle and liver insulin resistance and inhibits Glucose Stimulation of Insulin Secretion (GSIS). Elsner et al. [101] reported that 1) long-chain saturated NEFA, e.g. palmitic acid, are toxic to insulin-producing cells and 2) the toxicity is largely attributable to hydrogen peroxide generated by beta-oxidation of palmitic acid in extra-mitochondrial peroxisomes rather than in mitochondria.

In view of the association of insulin resistance, obesity, type 2 diabetes, and elevated plasma NEFA, it is noteworthy that Galuska et al. [88] reported that skeletal muscle plasma membrane $\mathrm{Na}^{+} / \mathrm{K}^{+}$ATPase activity was significantly decreased $(\sim 50 \%)$ in normal female Wistar rats fed a high fat diet for 4 weeks while undergoing swimming Exercise Training (SET). In contrast, insulin resistance (manifested by impaired glucose uptake) was not significantly increased (by $32 \%$ ) until 12 weeks on the diet + SET without any further reduction in plasma membrane $\mathrm{Na}^{+} / \mathrm{K}^{+}$-ATPase activity.

DeFronzo suggests insulin resistance in muscle, liver, and other insulin-sensitive tissues in type 2 diabetes is largely attributable to impaired phosphorylation of tyrosine residues on the beta chain of Insulin Receptor Substrate-1 (IRS-1). This impairs glucose transport into the cell, glucose phosphorylation, and downstream activation of multiple metabolic reactions including glucose oxidation and, primarily, glycogen synthesis [100].

Mima et al. [4] recently reported that insulin-induced phosphorylation of IRS-1, Akt, eNOS, and glycogen synthase kinase $3 a$ were selectively inhibited in glomeruli (versus renal tubules) of streptozotocin-diabetic rats and in Zucker-fatty insulin resistant rats versus nondiabetic controls and Zucker-lean rats. IRS-1 protein levels (but not mRNA levels) were decreased only in glomeruli of streptozotocin diabetic rats. Overexpression of IRS-1 or an inhibitor of PKC- $\beta$, a) reversed the inhibitory effects of high glucose, b) increased IRS-1 expression, and c) enhanced insulin action. These observations are consistent with the importance of impaired phosphorylation of IRS1 , as suggested by DeFronzo, and impaired Akt, eNOS, and glycogen synthase kinase $3 a$ activities, i.e. Metabolic Suppression, mediated by increased superoxide production by $\mathrm{NAD}(\mathrm{P}) \mathrm{H}$ oxidase augmented by PKC- $\beta$ as discussed earlier $[99,100]$.

Other investigators have drawn attention to Endoplasmic Reticulum (ER) stress as a key link to the relationships between insulin resistance, obesity, and type 2 diabetes [102-105]. Evidence supporting important roles of ER stress and oxidation of palmitic acid in peroxisomes is consistent with Metabolic Suppression as discussed above and with the observations of DeFronzo $[99,100]$ and Elsner et al. [101].

While the importance of increased superoxide and related ROS in the pathogenesis of diabetic complications is widely accepted, the metabolic imbalance(s) that fuel superoxide and ROS production remain controversial. Despite the primacy of increased oxidation of pyruvate (produced by increased glycolysis) in mitochondria suggested by Brownlee [18], Giacco and Brownlee [22], and Nishikawa et al. [26], recent observations support important roles for increased oxidation of a)sorbitol $[25,28,46]$ and b) lipids $[88,99-101,106]$ in the pathogenesis of diabetic complications.

The paucity of current research on the role of increased NADHc generated by sorbitol oxidation in fueling superoxide production appears to be largely attributable to 1) speculations of earlier investigators that were not supported by credible evidence and 2) flawed experimental protocols addressed in the main text and OSM of Ido et al. [25], Nyengaard et al. [27], and in Section 9. 6b. The sorbitol pathway has long been known to be present in pancreatic $\beta$-cells; several lines of evidence suggest that sequelae of increased sorbitol oxidation in $\beta$-cells may also impair insulin secretion (and eventual $\beta$-cell failure) in type 2 diabetes. $\mathrm{Na}^{+} / \mathrm{K}^{+}$-ATPase activity also has been shown by Owada et al. [97] to be significantly decreased in $\beta$-cells and islets from ob/ob mice incubated in hyperglycemic media.

Morrison et al. [107] reported that 1) sorbitol and fructose levels in freshly isolated unincubated islets from normal rats were substantially higher than in pancreatic acinar tissue and in plasma, and 2) incubation of islets in $17 v s .1 .7 \mathrm{mM}$ glucose significantly increased sorbitol levels. Gabbay and Tze [108] subsequently reported that glutaric acid (a relatively weak and nonspecific ARI) blocked both phases of GlucoseStimulated Insulin Secretion (GSIS) in the perfused rat pancreas and also suppressed increased insulin release evoked by tolbutamide. Addition of sorbitol to hyperglycemic perfusate containing glutaric acid and tolbutamide restored insulin secretion. They concluded their findings suggest that conversion of free intracellular glucose to sorbitol in $\beta$-cells is an essential step for GSIS. Their observations and conclusion: 1) are consistent with observations of numerous investigators cited by Ido et al. [25] that addition of sorbitol to normoglycemic incubation media evokes vascular dysfunction and metabolic imbalances like those caused by hyperglycemia in vivo and in vitro and 2) suggest that increased sorbitol oxidation and associated Metabolic Suppression in $\beta$-cells may contribute to impaired GSIS.

Flores et al. [109] reported that 2 different ARIs (ARI 509 and Tolrestat) prevented increased production of sorbitol by islets from normal rats and hereditarily diabetic Goto-Kakizaki rats incubated in 16.7 vs. $2.8 \mathrm{mM}$ glucose for 120 minutes, but did not impact associated increased insulin secretion. A possible explanation could be that sorbitol levels were not elevated long enough to generate sufficient superoxide to impair $\mathrm{Na}^{+} / \mathrm{K}^{+}$-ATPase activity, insulin synthesis, and insulin secretion. Unfortunately, they did not measure fructose levels (or lactate and pyruvate). As discussed earlier, 1) oxidation of sorbitol produces equimolar fructose and NADHc (Equation 6) and 2) effects of ARI are more closely linked to normalization of fructose than sorbitol levels.

Owada et al. [97] reported that incubation of single islets and single intact $\beta$-cells from adult obese (ob/ob) mice in $15 \mathrm{mM}$ glucose for 10 minutes (at $37^{\circ} \mathrm{C}$ ) decreased $\mathrm{Na}^{+} / \mathrm{K}^{+}$-ATPase activity $~ 50 \%$ that 1 ) was mediated by activation of $\mathrm{PKC}$ which increased phosphorylation of the a-subunit of $\mathrm{Na}^{+} / \mathrm{K}^{+}$-ATPase and 2) rapidly returned to control levels during a 10 minute washout with medium containing $3 \mathrm{mM}$ glucose. Arachidonic acid also decreased $\mathrm{Na}^{+} / \mathrm{K}^{+}$-ATPase activity, which was dose-dependent.

In view of the importance of increased $\mathrm{Ca}^{2+}$ levels in GSIS [110], it is noteworthy that Patterson et al. [111] and Wolf et al. [112] reported that NADHc regulates release of $\mathrm{Ca}^{2+}$ from endoplasmic reticulum by modulation of inositol 1,4,5-trisphosphate receptors (IP $\left.{ }_{3} \mathrm{R}\right)$ selectively bound to GA3P-DH to form an IP R/GA3P-DH complex that accounts for augmented $\mathrm{Ca}^{2+}$ release by NADHc formed by GA3P-DH (Figure 1). They suggest the $I_{3} R / G A 3 P-D H$ complex provides a means whereby cellular energetics can regulate $\mathrm{Ca}^{2+}$ signaling. Thus increased glycolysis evoked by hyperglycemia, hypoxia/ischemia, or strenuous exercise has the potential to increase intracellular $\mathrm{Ca}^{2+}$ levels that play a key role in mediating myocardial injury during ischemia-reperfusion $[111,112]$ as well as GSIS [110].

Increased $\mathrm{Ca}^{2+}$ release from intracellular stores of $\mathrm{Ca}^{2+}$ in endoplasmic reticulum by $\mathrm{IP}_{3} \mathrm{R} / \mathrm{GA} 3 \mathrm{P}-\mathrm{DH}$ complexes may occur more 
rapidly than uptake of extracellular $\mathrm{Ca}^{2+}$. This would be consistent with the need for rapid increases in GSIS and, concurrently, for activation by $\mathrm{Ca}^{2+}$ of cNOS in the vasculature of islets to augment blood flow for export of insulin to peripheral tissues. Observations and conclusions of Patterson et al. and Wolf et al. [111,112] also suggest a plausible mechanism for a) regulating $\mathrm{Ca}^{2+}$ release from the endoplasmic reticulum and b) different intracellular $\mathrm{Ca}^{2+}$ concentrations under basal conditions and during GSIS [110]. Observations of Tang et al. $[113,114]$ in nondiabetic and diabetic rats also are consistent with the observations and conclusions of Patterson et al. and Wolf et al. $[111,112]$. Tang et al. $[113,114]$ reported that myocardial ischemiareperfusion injury in nondiabetic rats was mediated by impaired activity of SERCA (Sarco(Endo)plasmic Reticulum $\mathrm{Ca}^{2+}$-ATPase) and RyR (Ryanodine Receptors) due to oxidative damage by sorbitol pathway-mediated oxidative stress that was prevented by ARI and by SDI. Tang et al. also observed that cardiac contractile dysfunction during acute hyperglycemia was mediated by impairment of SERCA and was prevented by ARI and SDI [113,114]. These observations of Tang et al. [113,114] are consistent with those of Ramasamy et al. [32] that aldose reductase inhibition protects diabetic and nondiabetic rat hearts from ischemic injury.

Decreased $\mathrm{Na}^{+} / \mathrm{K}^{+}$-ATPase activity in $\beta$-cells reported by Owada et al. [97] and desensitization of $\beta$-cells to glucose as a stimulus for GSIS suggested by Robertson [115] to protect $\beta$-cells from excessive stimulation and exhaustion are consistent with Metabolic Suppression proposed by Hochachka et al. [70-72] as a protective mechanism during hypoxia and, we suggest, by 'Hyperglycemic 'Pseudohypoxia' [46] that limits utilization of ATP to fuel insulin (protein) synthesis.

Robertson [115] suggests: "Inadequate insulin secretion from decompensated $\beta$-cells causes increasingly higher blood glucose levels that continually bathe the islet. This leads to a spectrum of consequences for $\beta$-cells including glucose desensitization, $\beta$-cell exhaustion and eventually glucose toxicity, i.e. a spectrum of physiology and pathophysiology. Desensitization is a pharmacological concept involving a cellular response to protect the cell from excessive stimulation".

Lastly, we call attention to recent publications of Pi et al. [116,117] emphasizing the importance of relatively small increases in ROS in fueling multiple redox-signaling pathways including GSIS versus toxic effects of excess increases in ROS that could impair GSIS and other redox signaling pathways resulting in eventual $\beta$-cell destruction. Toxic effects of excess ROS decrease the activity of protective antioxidant enzymes resulting in destruction of $\beta$-cells. This hypothesis is consistent with observations of Obrosova et al. [118] in the retina of diabetic rats that: 1 ) SOD activity was decreased $\sim 40 \%$ and was supranormalized by the ARI fidarestat, and 2) products of lipid peroxidation (MDAMalondialdehyde and 4-hydroxyalkenals) were increased 1.6-fold and also were prevented by fidarestat. In addition, Obrosova et al. [118] demonstrated that ROS were increased $\sim 2$-fold in bovine retinal endothelial cells (BREC) incubated in 30 vs. $5 \mathrm{mM}$ glucose that were prevented by fidarestat.

These observations, concepts, and hypotheses are consistent with the importance of numerous redox-signaling pathways critical for maintaining normal cell function and viability, and for modulating blood flows during hypoxia and increased physiological work as well as in diabetes. In numerous tissues (e.g. peripheral nerve, retina, and kidney) blood flows are increased early after the onset of diabetes; however, with longer duration and/or increased severity of diabetes excess ROS impair blood flow and damage cells and tissues manifested by complications of diabetes.
We suggest the information, concepts, and hypotheses summarized in this section warrant additional studies of the role of increased sorbitol oxidation in: 1) impairment of GSIS by human beta-cells and islets, 2) 'desensitization', i.e. Metabolic Suppression, of $\beta$-cells to protect them from excessive stimulation by hyperglycemia, and 3) mediating irreversible damage/destruction caused by chronic oxidative stress.

\section{6c. Linking decreased $\mathrm{Na}^{+} / \mathrm{K}^{+}$-ATPase activity and Metabolic Suppression to increased resistance to hypoxic/ischemic injury Hypoxic/Ischemic Preconditioning (HIP) in non-diabetics}

" $\mathrm{Na}^{+}$transport/pumping is by far the largest single ATPconsuming function in incubated normal rabbit retinas; i.e. $~ 50 \%$ of ATP generated in the cytoplasm by substrate phosphorylation and in mitochondria by oxidative phosphorylation" [119]. In normoxic liver cells the only ATP-consuming function more costly than ion pumping is protein turnover [70-72].

"One of the first and most dramatic effects of hypoxia on cell metabolic functions is a rapid, large-magnitude inhibition of protein synthesis. The disproportionate high percent of ATP consumed by $\mathrm{Na}^{+} / \mathrm{K}^{+}$-ATPase versus other functions in hypoxic versus normoxic cells and tissues is consistent with the critical importance of $\mathrm{Na}^{+} / \mathrm{K}^{+}$-ATPase activity in maintaining ionic gradients and membrane potentials essential for cell viability and function. Although hypoxia decreases ATP consumption by $\mathrm{Na}^{+} / \mathrm{K}^{+}$-ATPase, it is decreased less than in other enzymes" [72]. Observations of White et al. [120] support important roles for cAMP- and PKC-dependent inhibition of the cardiac $\mathrm{Na}^{+} / \mathrm{K}^{+}$ATPase pump via a shared downstream oxidative signaling pathway involving $\mathrm{NAD}(\mathrm{P}) \mathrm{H}$ oxidase activation and glutathionylation of the $\mathrm{Na}^{+} / \mathrm{K}^{+}$-ATPase pump $\beta_{1}$ subunit. This scenario is consistent with sequelae of increased NADHc (produced by sorbitol oxidation and by hypoxia) which 1) fuels activation of $\mathrm{PKC}, 2$ ) increases $\mathrm{NAD}(\mathrm{P}) \mathrm{H}$ oxidase activity, and 3) augments superoxide production (Figure 1).

While diabetes impairs $\mathrm{Na}^{+} / \mathrm{K}^{+}$-ATPase activity and related cellular functions in peripheral nerve, retina, blood vessels, myocardium (Section 6a), these same tissues are more resistant to hypoxic/ischemic injury [21,121-128] that (when tested) also is attenuated/reversed by ARI in diabetic humans and animals $[21,123]$. Ramasamy et al. [31,32] have demonstrated that 1 ) hearts in diabetic and non-diabetic rats also are protected from ischemic injury by ARIs and 2) the aldose reductase/sorbitol pathway plays a key role in mediating ischemic injury in nondiabetics and diabetics $[23,24,32,56]$.

Impaired electrical signaling function, e.g. nerve conduction velocity, amplitude, etc. in retina and nerve, decreased $\mathrm{Na}^{+} / \mathrm{K}^{+}$-ATPase activity, and increased resistance to hypoxic/ischemic injury evoked by diabetes are consistent with 1) protective effects of 'hypoxic-ischemic preconditioning' in non-diabetic subjects [129], i.e. brief periods of sublethal hypoxia/ischemia that protect cells and tissues from subsequent exposure to more severe or prolonged hypoxia/ischemia, and 2) the concept of 'Metabolic Suppression' characterized by Hochachka et al. [70-72] as an adaptive response to hypoxia/ischemia (and we propose to 'Hyperglycemic pseudohypoxia' [46]) that prolongs cell viability by reducing ATP consumption balanced by decreased rates of ATP synthesis.

Observations of Greene and Winegrad [130] are consistent with an important role for Metabolic Suppression characterized by Hochachka et al. [70-72] as an adaptive response to hypoxia/ischemia and, we suggest, 'Hyperglycemic pseudohypoxia' [46] that prolongs cell viability by reducing ATP consumption balanced by decreased rates of ATP synthesis in mediating diabetic neuropathy. Greene and Winegrad 
[130] and Greene et al. [131] reported: "In rabbits with alloxan diabetes of 14 days duration energy production in peripheral nerve is reduced by $25-30 \% \ldots$ which reflects a primary reduction in energy needs, i.e. a $31 \%$ decrease in the steady state rate of energy (ATP) utilization despite normal levels of ATP and P-creatine/creatine ratios...not a reduced capacity to produce energy from metabolic substrate." They also suggested "Decreased myoinositol and creatine+P-creatine concentrations in diabetic nerve fascicles indicated that maintenance of intracellular/extracellular gradients of myoinositol and creatine is impaired."

Greene and Lattimer et al. [74,75,132,133] demonstrated that decreased energy utilization in sciatic nerve was largely attributable to decreased utilization of ATP by $\mathrm{Na}^{+} / \mathrm{K}^{+}$-ATPase, especially the ouabain-inhibitable fraction of $\mathrm{Na}^{+} / \mathrm{K}^{+}$-ATPase. A sodium and energydependent saturable transport system in the tibial branch of the sciatic nerve of normal rabbits was responsible for at least $94 \%$ of myoinositol uptake at plasma myoinositol concentrations. Likewise, Simmons and Winegrad et al. [91-93] suggest that impaired aortic $\mathrm{Na}^{+} / \mathrm{K}^{+}$-ATPase activity caused by hyperglycemia is mediated by increased sorbitol pathway activity and linked to phosphatidylinositol synthesis and impaired myoinositol transport. These observations of Greene et al. are consistent with the concept of Metabolic Suppression as depicted in Figure 3.

These observations, together with increased resistance to hypoxic/ ischemic injury evoked by diabetes and by HIP in nondiabetics discussed above, are consistent with the hypothesis of Hochachka et al. [70-72] that decreased ATP turnover caused by hypoxia/ischemia and, we suggest, by 'Hyperglycemic Pseudohypoxia' [46] is mediated largely by 'ion channel arrest' and decreased $\mathrm{Na}^{+} / \mathrm{K}^{+}$-ATPase activity. Thus "The first lines of defense against hypoxia/anoxia include a drastic, albeit balanced, suppression of ATP demand and supply pathways; this regulation allows ATP levels to remain constant, even while ATP turnover rates greatly decline. The ATP requirements of ion pumping are down regulated by generalized 'channel' arrest in hepatocytes and by the arrest of specific ion channels in neurons. The disproportionate high percent of ATP consumed by $\mathrm{Na}^{+} / \mathrm{K}^{+}$ATPase versus other functions in hypoxic versus normoxic tissues is consistent with the critical importance of $\mathrm{Na}^{+} / \mathrm{K}^{+}$-ATPase activity in maintaining ionic gradients and membrane electrical potentials crucial for cell function and viability" [70-72]. This hypothesis also is consistent with evidence that consumption of ATP by $\mathrm{Na}^{+} / \mathrm{K}^{+}$-ATPase in the retina exceeds consumption of ATP by all other enzymes [119]. Although hypoxia decreases ATP consumption by $\mathrm{Na}^{+} / \mathrm{K}^{+}$-ATPase, as emphasized by Hochachka et al. [70-72], it is not reduced as much as ATP consumption by other enzymes.

The hypothesis of Hochachka et al. [70-72] also is supported by observations in diabetic humans and animals and the effects of HIP in nondiabetics consistent with 1) downregulation of cell functions and metabolic activities that utilize ATP for reactions not immediately crucial for maintaining cell viability, e.g. decreased synthesis of proteins including neuropeptides and acetylcholine $[134,135]$ and (we would add) insulin synthesis by $\beta$-cells, impaired axonal transport [136-138], and decreased catalysis of proteins, e.g. decreased mesangial matrix degradation in glomeruli [139-141], and 2) maintenance or activation of cell metabolism and functions critical for sustaining cell viability, e.g. activation of prosurvival kinases, e.g. Akt and Erk1/2 [142].

Observations of Jennings et al. in dogs [143] and of Lanza et al. in humans [144] also are consistent with the hypothesis of Hochachka et al. [70-72] and with observations of Greene et al. [74,130,132,133].
Jennings et al. [143] concluded that reduction in energy demand is an essential component of the mechanism of cardioprotection in preconditioned myocardium. Lanza et al. [144] concluded that ATP supply and demand in skeletal muscle during ischaemic work in vivo are balanced "not through higher glycolytic flux, but rather through increased metabolic economy and decreased rates of ATP consumption as fatigue ensues."

\section{ARI And C-Peptide Prevent Decreased $\mathrm{Na}^{+} / \mathrm{K}^{+}$- ATPase Activity}

Impaired $\mathrm{Na}^{+} / \mathrm{K}^{+}$-ATPase activity is associated with numerous metabolic imbalances, vascular and neural dysfunction, etc., the most important of which, we suggest, are consistent with direct and/or indirect sequelae of increased production of superoxide and related ROS fueled by NADHc which, when tested, are attenuated by ARI (addressed earlier in Section 6a) and by C-peptide (i.e. Connecting peptide) [6-12,96,98,145-155]. C-peptide is the 31 amino acid peptide connecting the $\mathrm{A}$ and $\mathrm{B}$ chains of pro-insulin and is secreted by $\beta$-cells equimolar to insulin.

C-peptide is a bioactive peptide [154] with numerous beneficial effects (in vivo and in vitro) in normalizing diabetes-induced metabolic imbalances and dysfunction in nerve, retina, kidney, and heart etc. as discussed above. C-peptide attenuates reactive oxygen species (ROS) generation by $\mathrm{NAD}(\mathrm{P}) \mathrm{H}$-oxidase and associated apoptosis of human aortic endothelial cells incubated in hyperglycemic media [147]. Cifarelli et al. concluded that C-peptide acts as an endogenous antioxidant in glucose-exposed endothelial cells [147]. C-peptide also reduces pro-inflammatory cytokine secretion from lipopolysaccharide (LPS) stimulated U-937 (human) monocytes, and adhesion of U-937 monocytes to human aortic endothelial cells (HAEC) under conditions of hyperglycemia [150]. The authors concluded the anti-inflammatory activity of C-peptide is likely due to suppression of NF-kB activation [150]. This conclusion is consistent with earlier observations reported by this group of investigators $[148,151]$.

Ido et al. [12] reported that sciatic nerve $\mathrm{Na}^{+} / \mathrm{K}^{+}$-ATPase activity was decreased $\sim 42 \%$ ( $P<0.005$ vs. controls) and sorbitol levels were increased $\sim 12.5$-fold ( $P<0.005$ vs controls) in rats with diabetes of 5-weeks duration. While C-peptide normalized $\mathrm{Na}^{+} / \mathrm{K}^{+}$-ATPase activity, it did not decrease sorbitol levels. Caudal nerve MNCV was decreased $\sim 12.6 \%$ ( $P<0.005$ vs. controls) that also was normalized by C-peptide. Plasma glucose levels were increased $\sim 3.5$-fold $(\mathrm{P}<0.005$ vs. controls) but were not decreased by C-peptide. In the same animals blood flows in the retina, sciatic nerve, and anterior uvea were significantly increased by diabetes $(\mathrm{P}<0.001)$ and were normalized by $\mathrm{C}$-peptide. Likewise, vascular albumin leakage was markedly increased $(\sim 2$-fold) in retina, sciatic nerve, and aorta $(P<0.001$ versus nondiabetics) and was markedly attenuated by $C$-peptide $(P<0.001$ vs. untreated diabetics).

Like the antioxidant pyruvate, C-peptide also markedly attenuates increased blood flows evoked by lactate infusion in retina, sciatic nerve, and skeletal muscle in normal rats [11]. Oxidation of lactate yields equimolar NADHc and pyruvate (Figure 1). However, as discussed earlier, changes in $\mathrm{NADHc}$ have a far greater impact than equimolar changes in $\mathrm{NAD}^{+}$, lactate, or pyruvate on $\mathrm{NADHc} / \mathrm{NAD}^{+} \mathrm{c}$ ratios. The observations in these reports provide strong evidence that $\mathrm{C}$-peptide (like pyruvate) is a potent natural endogenous antioxidant under normoglycemic conditions [11] as well as during hyperglycemia in diabetics [147-151] 


\section{Oxidation of Ethanol, like Oxidation of Sorbitol, Increases the Cellular NADH/NAD+ Ratio and ROS Production}

The importance of NADHc generated by oxidation of sorbitol in fueling superoxide production and associated complications of diabetes is consistent with observations in a variety of tissues that corresponding metabolic imbalances are associated with oxidation of ethanol by ethanol-DH.

Oxidation of ethanol by ethanol-DH, like oxidation of sorbitol by sorbitol-DH: 1) augments production of superoxide and ROS, 2) decreases $\mathrm{Na}^{+} / \mathrm{K}^{+}$-ATPase activity $[156,157]$, and 3) attenuates hypoxic/ischemic injury by evoking hypoxic/ischemic preconditioning (HIP) [158-163]. Likewise, pyruvate supplementation or inhibition of ethanol-DH prevents ethanol-induced increases in cellular NADHc/ $\mathrm{NAD}^{+} \mathrm{c}$ and ROS in normal rat hepatocytes [164]. The correspondence of decreased $\mathrm{Na}^{+} / \mathrm{K}^{+}$-ATPase activity, increased resistance to hypoxic/ ischemic injury, and hypoxic/ischemic preconditioning (HIP), all of which are linked to Metabolic Suppression, suggests that beneficial effects of modest alcohol consumption may be attributable, at least in part, to Metabolic Suppression.

An important difference in sorbitol versus ethanol toxicity is that sorbitol (a 6-carbon alcohol) is generated inside cells and accumulates to high levels because of its very slow rate of diffusion across cell membranes. In contrast, ethanol (a 2-carbon alcohol) readily diffuses across cell membranes. Therefore sorbitol toxicity is restricted largely to the cells in which it is formed whereas essentially all cells are potentially more susceptible to toxic effects of excess exogenous ethanol. Thus Metabolic Suppression and increased Resistance to Hypoxic Ischemic Injury (RHII), whether evoked by sorbitol oxidation, ethanol oxidation, or hypoxia/ischemia, may be largely sequelae of increased superoxide generated by NAD(P)H oxidases fueled by NADHc (Figure 1 ).

It also should be noted that increased $\mathrm{NADHc}$ and $\mathrm{NADH} / \mathrm{NAD}^{+} \mathrm{c}$ ratios produced by oxidation of sorbitol and by ethanol are essentially independent of glycolysis. In contrast, increases in NADHc evoked by hypoxia, ischemia, and strenuous exercise are generated largely via increased glycolysis by transfer of electrons and protons from GA3P to $\mathrm{NAD}^{+} \mathrm{c}$ by GA3P-DH coupled to reduction of $\mathrm{NAD}^{+} \mathrm{c}$ to NADHc followed by downstream production of equimolar pyruvate see (Figure 1). Since excess NADHc and pyruvate generated by increased glycolysis during hypoxia and strenuous exercise are produced much faster than during normoxic resting conditions, they are recombined by lactate$\mathrm{DH}$ to form lactate faster than it is removed by the vasculature under normal resting conditions. Rapidly increasing lactate levels cause product inhibition of lactate- $\mathrm{DH}$, which further restrains reoxidation of NADHc to lactate by lactate- $\mathrm{DH}$. The resulting increased levels of NADHc fuel superoxide production by NADHc-fueled NAD $(\mathrm{P})$ $\mathrm{H}$ oxidases (Figure 1). This scenario is consistent with observations discussed earlier that 1 ) increases in $\mathrm{NADH} / \mathrm{NAD}^{+} \mathrm{c}=$ lactate/pyruvate $\mathrm{x}$ $\mathrm{K}_{\mathrm{LDH}}$ (and associated metabolic imbalances) evoked by hypoxia and by hyperglycemia in incubated sciatic nerve endoneuria and retinas from normal rats are additive and 2) the increases evoked by hyperglycemia are prevented by ARI which has no impact on the associated increases evoked by hypoxia $[25,27]$.
9. Important Caveats to Experimental Observations and Speculations thought to be Inconsistent with an Important Role for Sorbitol Oxidation in the Pathogenesis of Diabetic Complications are Addressed by Ido et al. [25] and by Nyengaard et al. [27].

Example 1: We first suggested that increased NADHc produced by oxidation of sorbitol by sorbitol-dehydrogenase might contribute to oxidative stress and diabetic complications evoked by hyperglycemia in a perspective article in 1993 [46]. This hypothesis was not well received by other researchers based on observations in a surrogate animal model of diabetes, i.e. animals fed high galactose diets, develop many diabetes-like complications, e.g. cataracts, retinopathy, neuropathy, etc. However, it was well known that galactitol produced by oxidation of galactose is a poor substrate for sorbitol-dehydrogenase. Nevertheless, aldose reductase inhibitors prevented development of cataracts, retinopathy, neuropathy evoked by high galactose diets as well as corresponding complications evoked by diabetes. Observations of Ido et al. [25] demonstrated that markedly increased vascular albumin leakage in retina, sciatic nerve, and aorta in galactose-fed rats was prevented by ARI but not by SDI.

Nyengaard et al. [27] observed that 1) $\mathrm{NADH} / \mathrm{NAD}^{+} \mathrm{c}=$ lactate/ pyruvate ratios in normal rat retinas incubated in 30 vs. $5 \mathrm{mM}$ glucose for 2 hours were increased $65 \%$ versus $67 \%$ in $25 \mathrm{mM}$ sorbitol or 25 $\mathrm{mM}$ galactose, but were unaffected by $25 \mathrm{mM}$ galactitol. 2) Lactate production was increased $32 \%(\mathrm{P}<0.0001)$ by $25 \mathrm{mM}$ glucose, but was unaffected in retinas incubated in equimolar concentrations of sorbitol, galactose, or galactitol. 3) Triose phosphate levels were increased 33\% by $25 \mathrm{mM}$ glucose or sorbitol, and $47 \%$ by $25 \mathrm{mM}$ galactose, but were unaffected by $25 \mathrm{mM}$ galactitol.

Observations of Berry et al. [165] demonstrated that NADH/ $\mathrm{NAD}^{+} \mathrm{c}=$ lactate/pyruvate ratios increased 4-fold and galactonate levels increased 3-fold in normal human erythrocytes incubated in $25 \mathrm{mM}$ galactose. These observations were considered to support the likelihood that diabetes-like complications and increased NADHc/NAD ${ }^{+} \mathrm{c}$ ratios evoked by high galactose diets are mediated by oxidation of galactose to galactonate by galactose-dehydrogenase that was prevented by the ARI Tolrestat. As discussed earlier, Tolrestat also prevents the associated increase in $\mathrm{NADH} / \mathrm{NAD}^{+} \mathrm{c}=$ lactate/pyruvate ratios consistent with $\mathrm{ARI}$ effects on increased $\mathrm{NADH} / \mathrm{NAD}^{+} \mathrm{c}=$ lactate/pyruvate ratios in tissues of diabetics.

Example 2: Obrosova et al. [52] have 1)questioned the importance of free NADHc generated by sorbitol oxidation because "the rates of oxidation of $\mathrm{NADH}$ formation by glycolysis and its oxidation by the respiratory chain are incomparably higher than the rate of NADHc production by the sorbitol dehydrogenase reaction." and 2) claim "Hypoxia-like metabolic changes in the diabetic retina originate from aldose reductase, but not sorbitol dehydrogenase activity."

The first point overlooks the fact that NADHc generated by sorbitol oxidation (in contrast to NADHc generated by glycolysis) is uncoupled from downstream generation of equimolar 'antioxidant pyruvate' required for reoxidation of $\mathrm{NADHc}$ by lactate dehydrogenase. As a consequence NADHc levels rise 1.5-2-fold and are reoxidized to $\mathrm{NAD}^{+} \mathrm{C}$ largely by NAD $(\mathrm{P}) \mathrm{Hc}$-fueled oxidases $[48,49]$ coupled to production of superoxide and related reactive oxygen species (ROS), etc. [25]. The second point is based on experimental observations subject to several important caveats including (at least in part) the use of a biologically 
inactive inhibitor of sorbitol-DH (SDI-157) that is hydroxylated in vivo to form the active compound $[25,27]$.

\section{Summary}

We suggest oxidative stress and associated metabolic imbalances evoked by hyperglycemia in Type 1 and Type 2 diabetics appear to be largely sequelae of increased pro-oxidant NADHc (uncoupled from downstream equimolar 'antioxidant' pyruvate) produced by sorbitol oxidation. Since reoxidation of NADHc to $\mathrm{NAD}^{+} \mathrm{c}$ by lactate- $\mathrm{DH}$ is coupled to reduction of pyruvate to lactate, NADHc levels rise and 1) augment superoxide production by NADHc-fueled $\mathrm{NAD}(\mathrm{P}) \mathrm{H}$ oxidases coupled to reoxidation of $\mathrm{NADHc}$ to $\mathrm{NAD}^{+} \mathrm{C}$ which impairs $\mathrm{Na}^{+} / \mathrm{K}^{+}$-ATPase activity resulting in Metabolic Suppression and 2) contribute to product inhibition of GA3P-DH which increases triose phosphate (TP) levels. The combination of elevated NADHc levels and triose phosphates fuels (a) de novo synthesis of DAG which activates $\mathrm{PKC}$ that activates some isoforms of $\mathrm{NAD}(\mathrm{P}) \mathrm{H}$ oxidases to further augment superoxide production and related ROS (Figure 1) and (b) formation of methylglyoxal, a potent glycating agent that forms AGEs which impair the activity of numerous proteins and enzymes, the most important of which appears to be decreased $\mathrm{Na}^{+} / \mathrm{K}^{+}$-ATPase activity.

Metabolic Suppression evoked by hyperglycemia causes vascular and neural dysfunction, $\beta$-cell dysfunction, insulin resistance, etc. that are largely prevented/attenuated by (a) preventing sorbitol production by ARI or preventing sorbitol oxidation by SDI, (b) 'antioxidant' pyruvate supplementation, and (c) 'antioxidant' C-peptide. Increased oxidation of long chain non-esterified fatty acids (NEFA) also generates superoxide and related ROS and associated metabolic imbalances that impair $\mathrm{Na}^{+} / \mathrm{K}^{+}$-ATPase activity and evoke Metabolic Suppression. Prevention of obesity and normalization of plasma NEFA levels also attenuates oxidative stress, impaired $\mathrm{Na}^{+} / \mathrm{K}^{+}$-ATPase activity, and Metabolic Suppression caused by oxidation of NEFA.

\section{Acknowledgment}

We thank Drs. Peter J. Oates PhD, and Ronald G. Tilton PhD for their comments and suggestions based on reading an earlier draft of this manuscript. Studies performed in the Pathology Department at Washington University School of Medicine in St. Louis, MO were supported by NIH grants HL-39934 and EY06600 and by the Kilo Research Foundation (St. Louis, MO).

\section{References}

1. Hossain P, Kawar B, El Nahas M (2007) Obesity and diabetes in the developing world--a growing challenge. N Engl J Med 356: 213-215.

2. Huang ES, Basu A, O'Grady M, Capretta JC (2009) Projecting the future diabetes population size and related costs for the U.S. Diabetes Care 32: 22252229.

3. Calcutt NA, Cooper ME, Kern TS, Schmidt AM (2009) Therapies for hyperglycaemia-induced diabetic complications: From animal models to clinical trials. Nat Rev Drug Discov 8: 417-429.

4. Mima A, Ohshiro $Y$, Kitada M, Matsumoto $M$, Geraldes $P$, et al. (2011) Glomerular-specific protein kinase c- $\beta$-induced insulin receptor substrate-1 dysfunction and insulin resistance in rat models of diabetes and obesity. Kidney Int 79: 883-896.

5. Tiganis T (2011) Reactive oxygen species and insulin resistance: The good the bad and the ugly. Trends Pharmacol Sci 32: 82-89.

6. De La Tour DD, Raccah D, Jannot MF, Coste T, Rougerie C, et al. (1998) Erythrocyte $\mathrm{Na} / \mathrm{K}$ ATPase activity and diabetes: Relationship with $\mathrm{C}$-peptide level. Diabetologia 41: 1080-1084.

7. Djemli-Shipkolye A, Gallice P, Coste T, Jannot MF, Tsimaratos M, et al. (2000) The effects ex vivo and in vitro of insulin and $\mathrm{C}$-peptide on $\mathrm{Na} / \mathrm{K}$ adenosine triphosphatase activity in red blood cell membranes of type 1 diabetic patients. Metabolism 49: 868-872.
8. Ekberg K, Brismar $\mathrm{T}$, Johansson $\mathrm{BL}$, Lindstrom $\mathrm{P}$, Juntti-Berggren $\mathrm{L}$, et al. (2007) C-peptide replacement therapy and sensory nerve function in type 1 diabetic neuropathy. Diabetes Care 30: 71-76.

9. Kamiya H, Zhang W, Ekberg K, Wahren J, Sima AA (2006) C-peptide reverses nociceptive neuropathy in type 1 diabetes. Diabetes 55: 3581-3587.

10. Kamiya H, Zhang W, Sima AA (2009) The beneficial effects of c-peptide on diabetic polyneuropathy. Rev Diabet Stud 6: 187-202.

11. Ido Y, Chang K, Williamson JR (1998) C-peptide prevents increased blood flow induced by acute hyperlactatemia. Diabetes 47: A288.

12. Ido Y, Vindigni A, Chang K, Stramm L, Chance R, et al. (1997) Prevention of vascular and neural dysfunction in diabetic rats by c-peptide. Science 277 563-566.

13. Colhoun HM, Betteridge DJ, Durrington PN, Hitman GA, Neil HA, et al. (2004) Primary prevention of cardiovascular disease with atorvastatin in type 2 diabetes in the collaborative atorvastatin diabetes study (CARDS): Multicentre randomised placebo-controlled trial. Lancet 364: 685-696.

14. Haller H, Ito S, Izzo JL Jr, Januszewicz A, Katayama S, et al. (2011) Olmesartan for the delay or prevention of microalbuminuria in type 2 diabetes. N Engl J Med 364: 907-917.

15. Nathan DM, Zinman B, Cleary PA, Backlund JY, Genuth S, et al. (2009) Modernday clinical course of type 1 diabetes mellitus after 30 years' duration: The diabetes control and complications trial/epidemiology of diabetes interventions and complications and pittsburgh epidemiology of diabetes complications experience (1983-2005). Arch Intern Med 169: 1307-1316.

16. Holman RR, Paul SK, Bethel MA, Matthews DR, Neil HA (2008) 10-year followup of intensive glucose control in type 2 diabetes. N Engl J Med 359: 1577 1589.

17. Rosen P, Nawroth PP, King G, Moller W, Tritschler HJ, et al. (2001) The role of oxidative stress in the onset and progression of diabetes and its complications: A summary of a congress series sponsored by UNESCO-MCBN, the american diabetes association and the German Diabetes Society. Diabetes Metab Res Rev 17: 189-212.

18. Brownlee M (2001) Biochemistry and molecular cell biology of diabetic complications. Nature 414: 813-820

19. Cameron NE, Cotter MA, Basso M, Hohman TC (1997) Comparison of the effects of inhibitors of aldose reductase and sorbitol dehydrogenase on neurovascular function, nerve conduction and tissue polyol pathway metabolites in streptozotocin-diabetic rats. Diabetologia 40: 271-281.

20. Cameron NE, Cotter MA, Dines KC, Maxfield EK, Carey F, et al. (1994 Aldose reductase inhibition, nerve perfusion, oxygenation and function in streptozotocin-diabetic rats: dose-response considerations and independence from a myo-inositol mechanism. Diabetologia 37: 651-663.

21. Carrington AL, Ettlinger CB, Tomlinson DR (1994) Increased resistance to hypoxic conduction block in sciatic nerves of diabetic rats: effects of extracellular glucose concentration and of aldose reductase inhibition. J Diabetes Complications 8: 33-39

22. Giacco F, Brownlee M (2010) Oxidative stress and diabetic complications. Circ Res 107: 1058-1070.

23. Hwang YC, Kaneko M, Bakr S, Liao H, Lu Y, et al. (2004) Central role for aldose reductase pathway in myocardial ischemic injury. FASEB J 18: 1192-1199.

24. Hwang YC, Sato S, Tsai JY, Yan S, Bakr S, et al. (2002) Aldose reductase activation is a key component of myocardial response to ischemia. FASEB $J$ 16: $243-245$

25. Ido Y, Nyengaard JR, Chang K, Tilton RG, Kilo C, et al. (2010) Early neural and vascular dysfunctions in diabetic rats are largely sequelae of increased sorbitol oxidation. Antioxid Redox Signal 12: 39-51.

26. Nishikawa T, Edelstein D, Du XL, Yamagishi S, Matsumura T, et al. (2000) Normalizing mitochondrial superoxide production blocks three pathways of hyperglycaemic damage. Nature 404: 787-790.

27. Nyengaard JR, Ido Y, Kilo C, Williamson JR (2004) Interactions between hyperglycemia and hypoxia: implications for diabetic retinopathy. Diabetes 53 2931-2938.

28. Oates PJ (2008) Aldose reductase, still a compelling target for diabetic neuropathy. Curr Drug Targets 9: 14-36. 
Citation: Williamson JR, Ido Y (2012) Linking Diabetic Complications to Sorbitol Oxidation, Oxidative Stress and Metabolic Suppression. J Diabetes Metab 3: 219. doi:10.4172/2155-6156.1000219

29. Obrosova IG (2005) Increased sorbitol pathway activity generates oxidative stress in tissue sites for diabetic complications. Antioxid Redox Signal 7: 15431552.

30. Obrosova IG, Van Huysen C, Fathallah L, Cao XC, Greene DA, et al. (2002) An aldose reductase inhibitor reverses early diabetes-induced changes in peripheral nerve function, metabolism, and antioxidative defense. FASEB J 16: 123-125.

31. Ramasamy R, Goldberg IJ (2010) Aldose reductase and cardiovascular diseases, creating human-like diabetic complications in an experimental model. Circ Res 106: 1449-1458.

32. Ramasamy R, Oates PJ, Schaefer S (1997) Aldose reductase inhibition protects diabetic and nondiabetic rat hearts from ischemic injury. Diabetes 46 : 292-300.

33. Tanimoto T, Maekawa K, Okada S, Yabe-Nishimura C (1998) Clinical analysis of aldose reductase for differential diagnosis of the pathogenesis of diabetic complications. Analytica Chimica Acta 365: 285-292.

34. Markus HB, Raducha M, Harris H (1983) Tissue distribution of mammalian aldose reductase and related enzymes. Biochem Med 29: 31-45.

35. Hayman S, Kinoshita JH (1965) Isolation and properties of lens aldose reductase. J Biol Chem 240: 877-882.

36. Clements RS Jr, Winegrad Al (1972) Purification of alditol: NADP oxidoreductase from human placenta. Biochem Biophys Res Commun 47: 1473-1479.

37. Gabbay KH, Cathcart ES (1974) Purification and immunologic identification of aldose reductases. Diabetes 23: 460-468

38. Tanimoto T, Ohta M, Tanaka A, Ikemoto I, Machida T (1991) Purification and characterization of human testis aldose and aldehyde reductase. Int J Biochem 23: 421-428.

39. Mindnich RD, Penning TM (2009) Aldo-keto reductase (AKR) superfamily: genomics and annotation. Hum Genomics 3: 362-370.

40. Oates PJ (2002) Polyol pathway and diabetic peripheral neuropathy. Int Rev Neurobiol 50: 325-392.

41. Sanchez AP, Sharma K (2009) Transcription factors in the pathogenesis of diabetic nephropathy. Expert Rev Mol Med 11: e13

42. Srivastava SK, Yadav UC, Reddy AB, Saxena A, Tammali R, et al. (2011) Aldose reductase inhibition suppresses oxidative stress-induced inflammatory disorders. Chem Biol Interact 191: 330-338.

43. Mathews C, van Holde KE, Appling DR, Anthony-Cahill SJ (1999) Biochemistry. (4thedn), Prentice Hall, Redwood City, CA

44. Williamson DH, Lund P, Krebs HA (1967) The redox state of free nicotinamideadenine dinucleotide in the cytoplasm and mitochondria of rat liver. Biochem J 103: 514-527.

45. Poole RC, Halestrap AP (1993) Transport of lactate and other monocarboxylates across mammalian plasma membranes. Am J Physiol 264: C761-C782.

46. Williamson JR, Chang K, Frangos M, Hasan KS, Ido Y, et al. (1993) Hyperglycemic pseudohypoxia and diabetic complications. Diabetes 42: 801 813.

47. Tilton WM, Seaman C, Carriero D, Piomelli S (1991) Regulation of glycolysis in the erythrocyte: role of the lactate/pyruvate and NAD/NADH ratios. J Lab Clin Med 118: 146-152.

48. Kim IJ, Kim YK, Son SM, Hong KW, Kim CD (2003) Enhanced vascula production of superoxide in OLETF rat after the onset of hyperglycemia. Diabetes Res Clin Pract 60: 11-18.

49. Kim YK, Lee MS, Son SM, Kim IJ, Lee WS, et al. (2002) Vascular nadh oxidase is involved in impaired endothelium-dependent vasodilation in oletf rats, a model of type 2 diabetes. Diabetes 51: 522-527.

50. Obrosova IG, Fathallah L, Lang HJ, Greene DA (1999) Evaluation of a sorbitol dehydrogenase inhibitor on diabetic peripheral nerve metabolism: a prevention study. Diabetologia 42: 1187-1194.

51. Obrosova IG, Kador PF (2011) Aldose reductase / polyol inhibitors for diabetic retinopathy. Curr Pharm Biotechnol 12: 373-385.

52. Obrosova IG, Stevens MJ, Lang HJ (2001) Diabetes-induced changes in retinal NAD-redox status: Pharmacological modulation and implications for pathogenesis of diabetic retinopathy. Pharmacology 62: 172-180.
53. Cameron NE, Cotter MA, Low PA (1991) Nerve blood flow in early experimental diabetes in rats: relation to conduction deficits. Am J Physiol 261: E1-E8.

54. Chang K, Ido Y, LeJeune W, Williamson JR, Tilton RG (1997) Increased sciatic nerve blood flow in diabetic rats: assessment by "molecular" vs. particulate microspheres. Am J Physiol 273: E164-E173.

55. Ido Y, Chang K, LeJeune W, Tilton RG, Monafo WW, et al. (1997) Diabetes impairs sciatic nerve hyperemia induced by surgical trauma: implications for diabetic neuropathy. Am J Physiol 273: E174-184.

56. Li Q, Hwang YC, Ananthakrishnan R, Oates PJ, Guberski D, et al. (2008) Polyo pathway and modulation of ischemia-reperfusion injury in Type 2 diabetic BBZ rat hearts. Cardiovasc Diabetol 7: 33.

57. Halestrap AP (2009) Mitochondria and reperfusion injury of the heart--a holey death but not beyond salvation. J Bioenerg Biomembr 41: 113-121.

58. Halestrap AP (2010) A pore way to die: The role of mitochondria in reperfusion injury and cardioprotection. Biochem Soc Trans 38: 841-860.

59. Kerr PM, Suleiman MS, Halestrap AP (1999) Reversal of permeability transition during recovery of hearts from ischemia and its enhancement by pyruvate. Am J Physiol 276: H496-H502.

60. Sargent CA, Dzwonczyk S, Sleph P, Wilde M, Grover GJ (1994) Pyruvate increases threshold for preconditioning in globally ischemic rat hearts. Am J Physiol 267: H1403-H1409.

61. Beisswenger PJ, Howell SK, Smith K, Szwergold BS (2003) Glyceraldehyde-3phosphate dehydrogenase activity as an independent modifier of methylglyoxal levels in diabetes. Biochim Biophys Acta 1637: 98-106.

62. Thornalley PJ, Jahan I, Ng R (2001) Suppression of the accumulation of triosephosphates and increased formation of methylglyoxal in human red blood cells during hyperglycaemia by thiamine in vitro. J Biochem 129: 543-549.

63. Ceriello A, Esposito K, Piconi L, Ihnat MA, Thorpe JE, et al. (2008) Oscillating glucose is more deleterious to endothelial function and oxidative stress than mean glucose in normal and type 2 diabetic patients. Diabetes 57: 1349-1354.

64. Monnier L, Colette C, Dunseath GJ, Owens DR (2007) The loss of postprandial glycemic control precedes stepwise deterioration of fasting with worsening diabetes. Diabetes Care 30: 263-269

65. Node K, Inoue T (2009) Postprandial hyperglycemia as an etiological factor in vascular failure. Cardiovasc Diabetol 8: 23.

66. Roy S, Sen CK, Tritschler HJ, Packer L (1997) Modulation of cellular reducing equivalent homeostasis by alpha-lipoic acid. Mechanisms and implications for diabetes and ischemic injury. Biochem Pharmacol 53: 393-399.

67. Packer L, Kraemer K, Rimbach G (2001) Molecular aspects of lipoic acid in the prevention of diabetes complications. Nutrition 17: 888-895.

68. Gabbay KH (1973) The sorbitol pathway and the complications of diabetes. N Engl J Med 288: 831-836

69. Chalk C, Benstead TJ, Moore F (2007) Aldose reductase inhibitors for the treatment of diabetic polyneuropathy. Cochrane Database Syst Rev CD004572.

70. Hochachka PW (1986) Defense strategies against hypoxia and hypothermia Science 231: 234-241.

71. Hochachka PW, Buck LT, Doll CJ, Land SC (1996) Unifying theory of hypoxia tolerance: Molecular/metabolic defense and rescue mechanisms for surviving oxygen lack. Proc Natl Acad Sci U S A 93: 9493-9498.

72. Hochachka PW, Lutz PL (2001) Mechanism, origin, and evolution of anoxia tolerance in animals. Comp Biochem Physiol B Biochem Mol Biol 130: 435-459.

73. Borghini I, Geering K, Gjinovci A, Wollheim CB, Pralong WF (1994) In vivo phosphorylation of the $\mathrm{Na}, \mathrm{K}-\mathrm{ATP}$ ase alpha subunit in sciatic nerves of contro and diabetic rats: Effects of protein kinase modulators. Proc Natl Acad Sci U S A 91: 6211-6215.

74. Greene DA, Lattimer SA (1984) Impaired energy utilization and Na-K-ATPase in diabetic peripheral nerve. Am J Physiol 246: E311-E318.

75. Greene DA, Lattimer SA, Sima AA (1987) Sorbitol, phosphoinositides, and sodium-potassium-ATPase in the pathogenesis of diabetic complications. $N$ Engl J Med 316: 599-606.

76. Kjeldsen K, Braendgaard H, Sidenius P, Larsen JS, Norgaard A (1987) Diabetes decreases $\mathrm{Na}+\mathrm{K}+$ pump concentration in skeletal muscles, heart ventricular muscle, and peripheral nerves of rat. Diabetes 36: 842-848. 
Citation: Williamson JR, Ido Y (2012) Linking Diabetic Complications to Sorbitol Oxidation, Oxidative Stress and Metabolic Suppression. J Diabetes Metab 3: 219. doi:10.4172/2155-6156.1000219

Page 13 of 15

77. Raccah D, Coste T, Cameron NE, Dufayet D, Vague P, et al. (1998) Effect of the aldose reductase inhibitor tolrestat on nerve conduction velocity, $\mathrm{Na} / \mathrm{K}$ atpase activity, and polyols in red blood cells, sciatic nerve, kidney cortex, and kidney medulla of diabetic rats. J Diabetes Complications 12: 154-162.

78. Sonobe M, Yasuda H, Hisanaga T, Maeda K, Yamashita M, et al. (1991) Amelioration of nerve $\mathrm{Na}(+)-\mathrm{K}(+)$-ATPase activity independently of myo-inositol level by PGE1 analogue OP-1206.Alpha-CD in streptozocin-induced diabetic rats. Diabetes 40: 726-730.

79. Di Leo MA, Santini SA, Cercone S, Lepore D, Gentiloni Silveri N, et al. (2002) Chronic taurine supplementation ameliorates oxidative stress and $\mathrm{Na}+\mathrm{K}+$ ATPase impairment in the retina of diabetic rats. Amino Acids 23: 401-406.

80. Kowluru RA, Jirousek MR, Stramm L, Farid N, Engerman RL, et al. (1998) Abnormalities of retinal metabolism in diabetes or experimental galactosemia: V. Relationship between protein kinase $\mathrm{c}$ and atpases. Diabetes 47: 464-469.

81. MacGregor LC, Matschinsky FM (1986) Altered retinal metabolism in diabetes. II. Measurement of sodium-potassium ATPase and total sodium and potassium in individual retinal layers. J Biol Chem 261: 4052-4058.

82. Ottlecz A, Bensaoula T (1996) Captopril ameliorates the decreased $\mathrm{Na}+, \mathrm{K}(+)$ ATPase activity in the retina of streptozotocin-induced diabetic rats. Invest Ophthalmol Vis Sci 37: 1633-1641.

83. Ottlecz A, Garcia CA, Eichberg J, Fox DA (1993) Alterations in retinal Na+ $\mathrm{K}(+)$-ATPase in diabetes: Streptozotocin-induced and zucker diabetic fatty rats. Curr Eye Res 12: 1111-1121.

84. Hegde KR, Henein MG, Varma SD (2003) Establishment of mouse as an animal model for study of diabetic cataracts: biochemical studies. Diabetes Obes Metab 5: 113-119.

85. Obrosova IG, Fathallah L (2000) Evaluation of an aldose reductase inhibitor on lens metabolism, ATPases and antioxidative defense in streptozotocin-diabetic rats: An intervention study. Diabetologia 43: 1048-1055.

86. Banyasz T, Kovacs T (1998) Altered [3H]ouabain binding to cardiac muscle in insulin-dependent and non-insulin-dependent diabetic rats. Exp Physiol 83 65-76.

87. VIkovicova J, Javorkova V, Stefek M, Kysel'ova Z, Gajdosikova A, et al. (2006) Effect of the pyridoindole antioxidant stobadine on the cardiac $\mathrm{Na}(+), \mathrm{K}(+)-$ ATPase in rats with streptozotocin-induced diabetes. Gen Physiol Biophys 25: $111-124$

88. Galuska D, Kotova O, Barres R, Chibalina D, Benziane B, et al. (2009) Altered expression and insulin-induced trafficking of $\mathrm{Na}+\mathrm{K}+-\mathrm{ATPase}$ in rat skeletal muscle: effects of high-fat diet and exercise. Am J Physiol Endocrinol Metab 297: E38-E49.

89. Gupta S, Chough E, Daley J, Oates P, Tornheim K, et al. (2002) Hyperglycemia increases endothelial superoxide that impairs smooth muscle cell $\mathrm{Na}^{+}-\mathrm{K}^{+}$ ATPase activity. Am J Physiol Cell Physiol 282: C560-C566.

90. Ohara T, Sussman KE, Draznin B (1991) Effect of diabetes on cytosolic free ca2+ and $\mathrm{Na}(+)-\mathrm{K}(+)-A T P a s e$ in rat aorta. Diabetes 40: 1560-1563.

91. Simmons DA, Kern EF, Winegrad AI, Martin DB (1986)Basal phosphatidylinositol turnover controls aortic $\mathrm{Na}+/ \mathrm{K}+$ ATPase activity. J Clin Invest 77: 503-513.

92. Simmons DA, Winegrad Al (1989) Mechanism of glucose-induced (Na+, $\mathrm{K}+$ ATPase inhibition in aortic wall of rabbits. Diabetologia 32: 402-408.

93. Simmons DA, Winegrad Al (1991) Elevated extracellular glucose inhibits an adenosine-( $\mathrm{Na}+, \mathrm{K}+)$-ATPase regulatory system in rabbit aortic wall. Diabetologia 34: 157-163

94. Tesfamariam B, Gupta S, Oates PJ, Ruderman NB, Cohen RA (1993) Reduced $\mathrm{Na}(+)-\mathrm{K}+$ pump activity in diabetic rabbit carotid artery: Reversal by aldose reductase inhibition. Am J Physiol 265: H1189-H1194.

95. Rabini RA, Galassi R, Fumelli P, Dousset N, Solera ML, et al. (1994) Reduced $\mathrm{Na}(+)-\mathrm{K}(+)-$ ATPase activity and plasma lysophosphatidylcholine concentrations in diabetic patients. Diabetes 43: 915-919.

96. Vague P, Coste TC, Jannot MF, Raccah D, Tsimaratos M (2004) C-peptide, $\mathrm{Na}+, \mathrm{K}(+)-\mathrm{ATP} a \mathrm{se}$, and diabetes. Exp Diabesity Res 5: 37-50.

97. Owada S, Larsson O, Arkhammar P, Katz AI, Chibalin AV, et al. (1999) Glucose decreases $\mathrm{Na}+, \mathrm{K}+-\mathrm{ATP}$ ase activity in pancreatic beta-cells. An effect mediated via $\mathrm{Ca} 2+-$ independent phospholipase $\mathrm{A} 2$ and protein kinase c-dependent phosphorylation of the alpha-subunit. J Biol Chem 274: 2000-2008.
98. Nordquist L, Shimada K, Ishii T, Furuya DT, Kamikawa A, et al. (2010) Proinsulin C-peptide prevents type-1 diabetes-induced decrease of renal $\mathrm{Na}+$ K+-ATPase alpha1-subunit in rats. Diabetes Metab Res Rev 26: 193-199.

99. Defronzo RA (2009) Banting lecture. From the triumvirate to the ominous octet a new paradigm for the treatment of type 2 diabetes mellitus. Diabetes 58 : 773-795.

100.DeFronzo RA (2010) Insulin resistance, lipotoxicity, type 2 diabetes and atherosclerosis: the missing links. The claude Bernard Lecture 2009. Diabetologia 53: 1270-1287.

101. Elsner M, Gehrmann W, Lenzen S (2011) Peroxisome-generated hydrogen peroxide as important mediator of lipotoxicity in insulin-producing cells. Diabetes 60: 200-208

102. Cunard R, Sharma K (2011) The endoplasmic reticulum stress response and diabetic kidney disease. Am J Physiol Renal Physiol 300: F1054-F1061.

103. Muoio DM, Newgard CB (2004) Biomedicine. Insulin resistance takes a trip through the ER. Science 306: 425-426.

104. Ozcan U, Cao Q, Yilmaz E, Lee AH, Iwakoshi NN, et al. (2004) Endoplasmic reticulum stress links obesity, insulin action, and type 2 diabetes. Science 306: 457-461.

105. Ozcan U, Yilmaz E, Ozcan L, Furuhashi M, Vaillancourt E, et al. (2006) Chemical chaperones reduce ER stress and restore glucose homeostasis in a mouse model of type 2 diabetes. Science 313: 1137-1140.

106. Cunha JM, Jolivalt CG, Ramos KM, Gregory JA, Calcutt NA, et al. (2008) Elevated lipid peroxidation and DNA oxidation in nerve from diabetic rats: effects of aldose reductase inhibition, insulin, and neurotrophic factors. Metabolism 57: 873-881.

107. Morrison AD, Winegrad AI, Fink CJ, Lacy PE (1970) Sorbitol synthesis in isolated rat pancreatic islets. Biochem Biophys Res Commun 38: 491-495.

108. Gabbay KH, Tze WJ (1972) Inhibition of glucose-induced release of insulin by aldose reductase inhibitors. Proc Natl Acad Sci U S A 69: 1435-1439.

109. Flores LE, Gagliardino JJ, Sener A, Malaisse WJ (1998) Effects of two aldose reductase inhibitors upon sorbitol output, D-glucose metabolism and insulin release in islets from normal and hereditarily diabetic rats. Pharmacol Res 37: 493-496.

110. Kaplin AI, Snyder SH, Linden DJ (1996) Reduced nicotinamide adenine dinucleotide-selective stimulation of inositol 1,4,5-trisphosphate receptors mediates hypoxic mobilization of calcium. J Neurosci 16: 2002-2011.

111. Patterson RL, van Rossum DB, Kaplin Al, Barrow RK, Snyder SH (2005) Inositol 1,4,5-trisphosphate receptor/GAPDH complex augments Ca2+ release via locally derived NADH. Proc Natl Acad Sci U S A 102: 1357-1359.

112. Wolf BA, Colca JR, Turk J, Florholmen J, McDaniel ML (1988) Regulation of $\mathrm{Ca}^{+}$homeostasis by islet endoplasmic reticulum and its role in insulin secretion. Am J Physiol 254: E121-E136.

113. Tang WH, Cheng WT, Kravtsov GM, Tong XY, Hou XY, et al. (2010) Cardiac contractile dysfunction during acute hyperglycemia due to impairment of SERCA by polyol pathway-mediated oxidative stress. Am J Physiol Cell Physiol 299: C643-653.

114. Tang WH, Kravtsov GM, Sauert M, Tong XY, Hou XY, et al. (2010) Polyol pathway impairs the function of SERCA and RyR in ischemic-reperfused rat hearts by increasing oxidative modifications of these proteins. $\mathrm{J} \mathrm{Mol} \mathrm{Cell}$ Cardiol 49: 58-69.

115. Robertson RP (2009) Beta-cell deterioration during diabetes: What's in the gun? Trends Endocrinol Metab 20: 388-393.

116. Pi J, Bai Y, Zhang Q, Wong V, Floering LM, et al. (2007) Reactive oxygen species as a signal in glucose-stimulated insulin secretion. Diabetes 56: 17831791.

117. Pi J, Zhang Q, Fu J, Woods CG, Hou Y, et al. (2010) ROS signaling, oxidative stress and Nrf2 in pancreatic beta-cell function. Toxicol Appl Pharmacol 244 77-83.

118. Obrosova IG, Minchenko AG, Vasupuram R, White L, Abatan OI, et al. (2003) Aldose reductase inhibitor fidarestat prevents retinal oxidative stress and vascular endothelial growth factor overexpression in streptozotocin-diabetic rats. Diabetes 52: 864-871.

119. Ames A 3rd, Li YY, Heher EC, Kimble CR (1992) Energy metabolism of rabbit 
retina as related to function: high cost of $\mathrm{Na}+$ transport. J Neurosci 12: 840853.

120. White CN, Liu CC, Garcia A, Hamilton EJ, Chia KK, et al. (2010) Activation of camp-dependent signaling induces oxidative modification of the cardiac $\mathrm{Na}+\mathrm{K}+$ pump and inhibits its activity. J Biol Chem 285: 13712-13720.

121. Calcutt NA, Ettlinger CB, Carrington AL, Diemel L, Tomlinson DR (1991) Resistance to hypoxic conduction block in sciatic nerves of rats with streptozotocin-induced diabetes mellitus. J Neurol Sci 103: 116-123.

122. Price DE, Airey CM, Alani SM, Wales JK (1988) Effect of aldose reductase inhibition on nerve conduction velocity and resistance to ischemic conduction block in experimental diabetes. Diabetes 37: 969-973.

123. Price DE, Alani SM, Wales JK (1991) Effect of aldose reductase inhibition on resistance to ischemic conduction block in diabetic subjects. Diabetes Care 14: 411-413.

124. Rimmer T, Linsenmeier RA (1993) Resistance of diabetic rat electroretinogram to hypoxemia. Invest Ophthalmol Vis Sci 34: 3246-3252.

125. Seneviratne KN, Peiris OA (1968) The effect of ischaemia on the excitability of sensory nerves in diabetes mellitus. J Neurol Neurosurg Psychiatry 31: 348353.

126. Seneviratne KN, Peiris OA (1969) The effects of hypoxia on the excitability of the isolated peripheral nerves of alloxan-diabetic rats. J Neurol Neurosurg Psychiatry 32: 462-469.

127. Tani M, Neely JR (1988) Hearts from diabetic rats are more resistant to in vitro ischemia: Possible role of altered Ca2+ metabolism. Circ Res 62: 931-940.

128. Liu Y, Thornton JD, Cohen MV, Downey JM, Schaffer SW (1993) Streptozotocin-induced non-insulin-dependent diabetes protects the heart from infarction. Circulation 88: 1273-1278.

129. Monteiro P, Goncalves L, Providencia LA (2005) Diabetes and cardiovascular disease: the road to cardioprotection. Heart 91: 1621-1625.

130. Greene DA, Winegrad Al (1981) Effects of acute experimental diabetes on composite energy metabolism in peripheral nerve axons and Schwann cells. Diabetes 30: 967-974.

131. Greene DA, Yagihashi S, Lattimer SA, Sima AA (1984) Nerve $\mathrm{Na}^{+}-\mathrm{K}^{+}-A T P a s e$ conduction, and myo-inositol in the insulin-deficient bb rat. Am J Physiol 247 E534-E539.

132. Greene DA, Lattimer S, Ulbrecht J, Carroll P (1985) Glucose-induced alterations in nerve metabolism: Current perspective on the pathogenesis of diabetic neuropathy and future directions for research and therapy. Diabetes Care 8: 290-299.

133. Greene DA, Lattimer SA (1982) Sodium- and energy-dependent uptake of myo-inositol by rabbit peripheral nerve. Competitive inhibition by glucose and lack of an insulin effect. J Clin Invest 70: 1009-1018.

134. Diemel LT, Stevens EJ, Willars GB, Tomlinson DR (1992) Depletion of substance $P$ and calcitonin gene-related peptide in sciatic nerve of rats with experimental diabetes; effects of insulin and aldose reductase inhibition. Neurosci Lett 137: 253-256.

135. Gibson GE, Blass JP (1976) Impaired synthesis of acetylcholine in brain accompanying mild hypoxia and hypoglycemia. J Neurochem 27: 37-42.

136. Schmidt RE, Matschinsky FM, Godfrey DA, Williams AD, McDougal DB Jr (1975) Fast and slow axoplasmic flow in sciatic nerve of diabetic rats. Diabetes 24: 1081-1085.

137. Tomlinson DR, Moriarty RJ, Mayer JH (1984) Prevention and reversal of defective axonal transport and motor nerve conduction velocity in rats with experimental diabetes by treatment with the aldose reductase inhibitor sorbinil. Diabetes 33: 470-476.

138. Tomlinson DR, Sidenius P, Larsen JR (1986) Slow component-a of axonal transport, nerve myo-inositol, and aldose reductase inhibition in streptozocindiabetic rats. Diabetes 35: 398-402.

139. McLennan SV, Fisher EJ, Yue DK, Turtle JR (1994) High glucose concentration causes a decrease in mesangium degradation. A factor in the pathogenesis of diabetic nephropathy. Diabetes 43: 1041-1045.

140. Singh R, Alavi N, Singh AK, Leehey DJ (1999) Role of angiotensin ii in glucoseinduced inhibition of mesangial matrix degradation. Diabetes 48: 2066-2073.

141.Singh R, Song RH, Alavi N, Pegoraro AA, Singh AK, et al. (2001) High glucose decreases matrix metalloproteinase-2 activity in rat mesangial cells via transforming growth factor-beta1. Exp Nephrol 9: 249-257.

142. Hausenloy DJ, Tsang A, Mocanu MM, Yellon DM (2005) Ischemic preconditioning protects by activating prosurvival kinases at reperfusion. Am J Physiol Heart Circ Physiol 288: H971-H976.

143. Jennings RB, Sebbag L, Schwartz LM, Crago MS, Reimer KA (2001) Metabolism of preconditioned myocardium: Effect of loss and reinstatement of cardioprotection. J Mol Cell Cardiol 33: 1571-1588.

144. Lanza IR, Wigmore DM, Befroy DE, Kent-Braun JA (2006) In vivo ATP production during free-flow and ischaemic muscle contractions in humans. $J$ Physiol 577: 353-367.

145. Hills CE, Brunskill NJ (2009) Cellular and physiological effects of C-peptide. Clin Sci (Lond) 116: 565-574.

146. Hills CE, Brunskill NJ, Squires PE (2010) C-peptide as a therapeutic tool in diabetic nephropathy. Am J Nephrol 31: 389-397.

147. Cifarelli V, Geng X, Styche A, Lakomy R, Trucco M, et al. (2011) C-peptide reduces high-glucose-induced apoptosis of endothelial cells and decreases $\mathrm{NAD}(\mathrm{P}) \mathrm{H}$-oxidase reactive oxygen species generation in human aortic endothelial cells. Diabetologia 54: 2702-2712.

148. Cifarelli V, Luppi P, Tse HM, He J, Piganelli J, et al. (2008) Human proinsulin C-peptide reduces high glucose-induced proliferation and NF-kappaB activation in vascular smooth muscle cells. Atherosclerosis 201: 248-257.

149. Forst T, Hach T, Kunt T, Weber MM, Pfutzner A (2009) Molecular effects of C-peptide in microvascular blood flow regulation. Rev Diabet Stud 6: 159-167.

150. Haidet J, Cifarelli V, Trucco M, Luppi P (2012) C-peptide reduces proinflammatory cytokine secretion in LPS-stimulated U937 monocytes in condition of hyperglycemia. Inflamm Res 61: 27-35.

151.Luppi P, Cifarelli V, Tse H, Piganelli J, Trucco M (2008) Human C-peptide antagonises high glucose-induced endothelial dysfunction through the nuclear factor-kappaB pathway. Diabetologia 51: 1534-1543.

152. Mughal RS, Scragg JL, Lister P, Warburton P, Riches K, et al. (2010) Cellula mechanisms by which proinsulin C-peptide prevents insulin-induced neointima formation in human saphenous vein. Diabetologia 53: 1761-1771.

153. Samnegard B, Jacobson SH, Jaremko G, Johansson BL, Ekberg K, et al. (2005) C-peptide prevents glomerular hypertrophy and mesangial matrix expansion in diabetic rats. Nephrol Dial Transplant 20: 532-538.

154. Wahren J, Ekberg K, Jornvall $\mathrm{H}$ (2007) C-peptide is a bioactive peptide. Diabetologia 50: 503-509.

155. Young LH, Ikeda Y, Scalia R, Lefer AM (2000) C-peptide exerts cardioprotective effects in myocardial ischemia-reperfusion. Am J Physiol Heart Circ Physio 279: $\mathrm{H} 1453-\mathrm{H} 1459$

156. Botta P, de Souza FM, Sangrey T, De Schutter E, Valenzuela CF (2010) Alcohol excites cerebellar golgi cells by inhibiting the $\mathrm{Na}+\mathrm{K}+$ ATPase. Neuropsychopharmacology 35: 1984-1996.

157. Maturu P, Vaddi DR, Pannuru P, Nallanchakravarthula V (2010) Alterations in erythrocyte membrane fluidity and $\mathrm{Na}+/ \mathrm{K}+-$ ATPase activity in chronic alcoholics. Mol Cell Biochem 339: 35-42.

158. Gross ER, Gare M, Toller WG, Kersten JR, Warltier DC, et al. (2001) Ethano enhances the functional recovery of stunned myocardium independent of K(ATP) channels in dogs. Anesth Analg 92: 299-305.

159. Guiraud A, de Lorgeril M, Boucher F, Berthonneche C, Rakotovao A, et at. (2004) Cardioprotective effect of chronic low dose ethanol drinking: Insights into the concept of ethanol preconditioning. J Mol Cell Cardiol 36: 561-566.

160. Kehl F, Krolikowski JG, LaDisa JF Jr, Kersten JR, Warltier DC, et al. (2003) Adenosine type 1 (A1) receptors mediate protection against myocardia infarction produced by chronic, intermittent ingestion of ethanol in dogs. Int $J$ Cardiol 88: 175-182

161. Miyamae M, Diamond I, Weiner MW, Camacho SA, Figueredo VM (1997) Regular alcohol consumption mimics cardiac preconditioning by protecting against ischemia-reperfusion injury. Proc Natl Acad Sci U S A 94: 3235-3239.

162. Pagel PS, Kersten JR, Warltier DC (2004) Mechanisms of myocardial protection produced by chronic ethanol consumption. Pathophysiology 10 : 121-129. 
Citation: Williamson JR, Ido Y (2012) Linking Diabetic Complications to Sorbitol Oxidation, Oxidative Stress and Metabolic Suppression. J Diabetes Metab 3: 219. doi:10.4172/2155-6156.1000219

Page 15 of 15

163. Pagel PS, Krolikowski JG, Kehl F, Mraovic B, Kersten JR, et al. (2002) The role of mitochondrial and sarcolemmal K(ATP) channels in canine ethanolinduced preconditioning in vivo. Anesth Analg 94: 841-848.

164. Bailey SM, Cunningham CC (1998) Acute and chronic ethanol increases reactive oxygen species generation and decreases viability in fresh, isolated rat hepatocytes. Hepatology 28: 1318-1326.

165. Berry GT, Wehrli S, Reynolds R, Palmieri M, Frangos M, et al. (1998) Elevation of erythrocyte redox potential linked to galactonate biosynthesis: elimination by tolrestat. Metabolism 47: 1423-1428. 